\title{
New Delhi Metallo-beta-lactamase around the world: An eReview using Google Maps
}

M Berrazeg ${ }^{1,2}$, S M Diene ${ }^{1}$, L Medjahed ${ }^{3}$, P Parola ${ }^{1}$, M Drissi ${ }^{2}$, D Raoult ${ }^{1}$, J M Rolain (jean-marc.rolain@univ-amu.fr) ${ }^{1}$

1. Aix-Marseille Université, Unité de Recherche en Maladies Infectieuses et Tropicales Emergentes, Faculté de Médecine et de Pharmacie, Marseille, France

2. Laboratoire Antibiotiques, Antifongiques: physico- chimie, Synthèse et Activité Biologiques, Faculté des Sciences de la Nature, de la Vie, de la Terre et de l'Univers, Université Abou Bekr Belkaid, Tlemcen, Algeria

3. Département d’Informatique, Faculté de technologie, Université Abou Bekr Belkaid, Tlemcen, Algeria

Citation style for this article:

Berrazeg M, Diene SM, Medjahed L, Parola P, Drissi M, Raoult D, Rolain JM. New Delhi Metallo-beta-lactamase around the world: An eReview using Google Maps. Euro Surveill. 2014;19(20):pii=20809. Available online: http://www.eurosurveillance.org/ViewArticle.aspx?Articleld=20809

Gram-negative carbapenem-resistant bacteria, in particular those producing New Delhi Metallo-betalactamase-1 (NDM-1), are a major global health problem. To inform the scientific and medical community in real time about worldwide dissemination of isolates of NDM-1-producing bacteria, we used the PubMed database to review all available publications from the first description in 2009 up to 31 December 2012, and created a regularly updated worldwide dissemination map using a web-based mapping application. We retrieved 33 reviews, and 136 case reports describing 950 isolates of NDM-1-producing bacteria. Klebsiella pneumoniae $(n=359)$ and Escherichia coli $(n=268)$ were the most commonly reported bacteria producing NDM-1 enzyme. Several case reports of infections due to imported NDM-1 producing bacteria have been reported in a number of countries, including the United Kingdom, Italy, and Oman. In most cases (132/153, 86.3\%), patients had connections with the Indian subcontinent or Balkan countries. Those infected were originally from these areas, had either spent time and/ or been hospitalised there, or were potentially linked to other patients who had been hospitalised in these regions. By using Google Maps, we were able to trace spread of NDM-1-producing bacteria. We strongly encourage epidemiologists to use these types of interactive tools for surveillance purposes and use the information to prevent the spread and outbreaks of such bacteria.

\section{Introduction}

New Delhi Metallo-beta-lactamase-1 (NDM-1) is the most recently discovered transferable molecular class $B$ beta-lactamase. Unlike class A, C and D beta-lactamases, NDM-1 has zinc ions at its active site, and it can hydrolyse all beta-lactam antimicrobials except for monobactam [1-3]. Moreover, most NDM-1-positive bacteria are resistant to a wide variety of other antimicrobial classes and carry several additional resistance mechanisms for example to aminoglycosides, fluoroquinolones, macrolides and sulfonamides, leaving few or no therapeutic options [4-8]. The putative original source of the bla $a_{\mathrm{NDM}-1}$ gene could be from a chromosome of plant pathogens, such as Pseudoxanthomonas and related bacteria that are widespread in the environment [9].

The first published reports of infections involved individuals who had received medical care in India. The precise geographic origin and the time of the first appearance of the $b / a_{\mathrm{NDM}-1}$ genes are unknown, however. The first NDM-1-producing bacteria were isolated from a Swedish resident of Indian origin who contracted a urinary tract infection caused by carbapenem-resistant Klebsiella pneumoniae while he was in New Delhi in late 2007 , hence the name [10]. At present, most bacteria isolated worldwide have originated from people colonised/infected (with or without showing infection symptoms) on the Indian subcontinent who have then traveled elsewhere [3,11]. However, it is presumed that there are other reservoirs of colonised/infected patients in the Balkan countries [12]. There is also an unknown burden in the Middle East, where people often travel to and from the Indian subcontinent [13].

NDM-1-producing bacteria have been recovered from many infection sites; they have been found in patients with urinary tract infections, pneumonia, septicaemia, wound infections and device-associated infections $[7,14,15]$. Both hospital- and community-acquired infections have been reported $[7,14,16]$. The following factors have influenced the geographically widespread emergence of these NDM-1-producing bacteria: the increase in long-distance travel [17], the increase in international travel to access medical care [18] and widespread access to broad spectrum antibiotics. The latter is due to the fact that in many countries, antibiotics can be obtained without a prescription because of the strong economic incentives to sell and use them [19]. 


\section{FIGURE 1}

Number of articles retrieved from PubMED database using keywords 'NDM-1' or 'New Delhi Metallo-betalactamase-1' per year, 1 December 2009-31 December $2012(n=235)$

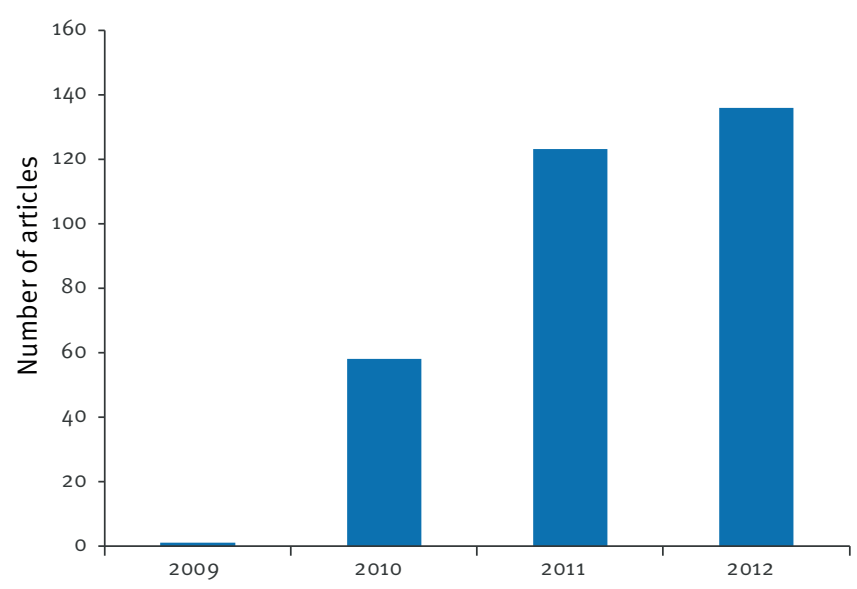

Year

Given the volume of international travel, the quality of hygienic standards in many countries, and the number of humans carrying NDM-1-producing bacteria, it is likely that these bacteria will continue to spread worldwide [15]. There has been an increase in the number of articles about the 'New Delhi Metallo-betalactamase-1' enzyme added to the PubMed database since 2010 (Figure 1), but the current spread of NDM1-prodcucing bacteria is likely broader than the published reports suggest.

To conduct an eReview of all published isolates worldwide as of end 2012, we used in this article the Google Maps application to simplify and accelerate access to documentation, organise information about published isolates of NDM-1-producing bacteria and provide realtime information to the scientific and medical community about published isolates of NDM-1-producing bacteria around the world. Few studies have used this type of automated system to investigate, in real time, web-based electronic reports for the purpose of monitoring the spread of infectious diseases caused by influenza $A\left(\mathrm{H}_{1} \mathrm{~N}_{1}\right)$ and Dengue viruses $[20,21]$. Google Maps is a widely available, free of charge, and extremely powerful tool for visualisation with a simple, intuitive interface that requires little training or experience to use it. It can be run on any conventional desktop computer or laptop, and there is also a Google Maps application available for mobile phones [22].

Because a visual representation of scientific data is more informative than a written description, this article describes the development of an internet-based mapping and geo-referencing application for tracking the worldwide dissemination of NDM-1-producing bacteria as an example of this application. We analysed in this article the medical literature from the first case report in December 2009 until 31 December 2012.

\section{Methods}

Literature search in the PubMed database

We started by retrieving all published articles from the PubMed database using 'NDM-1' and 'New Delhi Metallo-beta-lactamase-1' as keywords, from the first case report in 2009 until 31 December 2012. We included in our analysis only the first publications that reported on isolates of NDM-1-producing bacteria. We excluded all consecutive publications about the same isolates with descriptions of genomic or protein analysis or others types of analysis. After reading and analysing the full article, we specifically extracted the year of detection of the isolates, their geographic location (city and country), the NDM-1-producing bacterial species, the number of published isolates, the type of case reports, the title and the full reference for the published article, the link to the isolates description in PubMed database.

A case report of NDM-1-producing bacteria was defined as a patient from whom one or more Gram-negative bacteria had been isolated that produce NDM-1 or when an isolate from the environment contains NDM1-producing bacteria, with the test result confirmed by an expert laboratory. We categorised case reports into five different types: (i) imported human infection case reports (NDM-1-producing bacteria isolated from patients with a history of recent travel or contact with healthcare facilities abroad before the detection of bla $a_{\text {NDM-1 }}$ gene), (ii) autochthonous human infection case reports (reports of patients with an infection caused by NDM-1-producing bacteria who did not have contact with a travel-associated case), (iii) autochthonous human carriage case reports(carriage of NDM1-producing bacteria in patients who did not have contact with a travel-associated case), (iv) autochthonous environmental case reports (a description of NDM-1-producing bacteria in the hospital or the external environment) and (v) autochthonous human carriage and environmental case reports (a description of the two types of cases in the same article).

\section{Construction of Google Maps}

We used Google Maps to create an electronic map depicting the geographic locations of case reports of NDM-1-producing bacteria listed in our database. Google provides full documentation for Google Maps, tutorials and other materials to help users take full advantage of the application (https://maps.google. com). The locations on the map were tagged using different symbols for each type of report of NDM-1producing bacteria. Clicking the tags will provide a display of the important information about the selected article (the same information stored in the columns in the database). If there are several tags within close proximity to one another, the tags expand outward to facilitate selection of a single tag. Google Maps navigation tabs in the upper left of the screen can be used to zoom in on an area of interest. Alternatively, one can double-click on one of the locations in the table of 


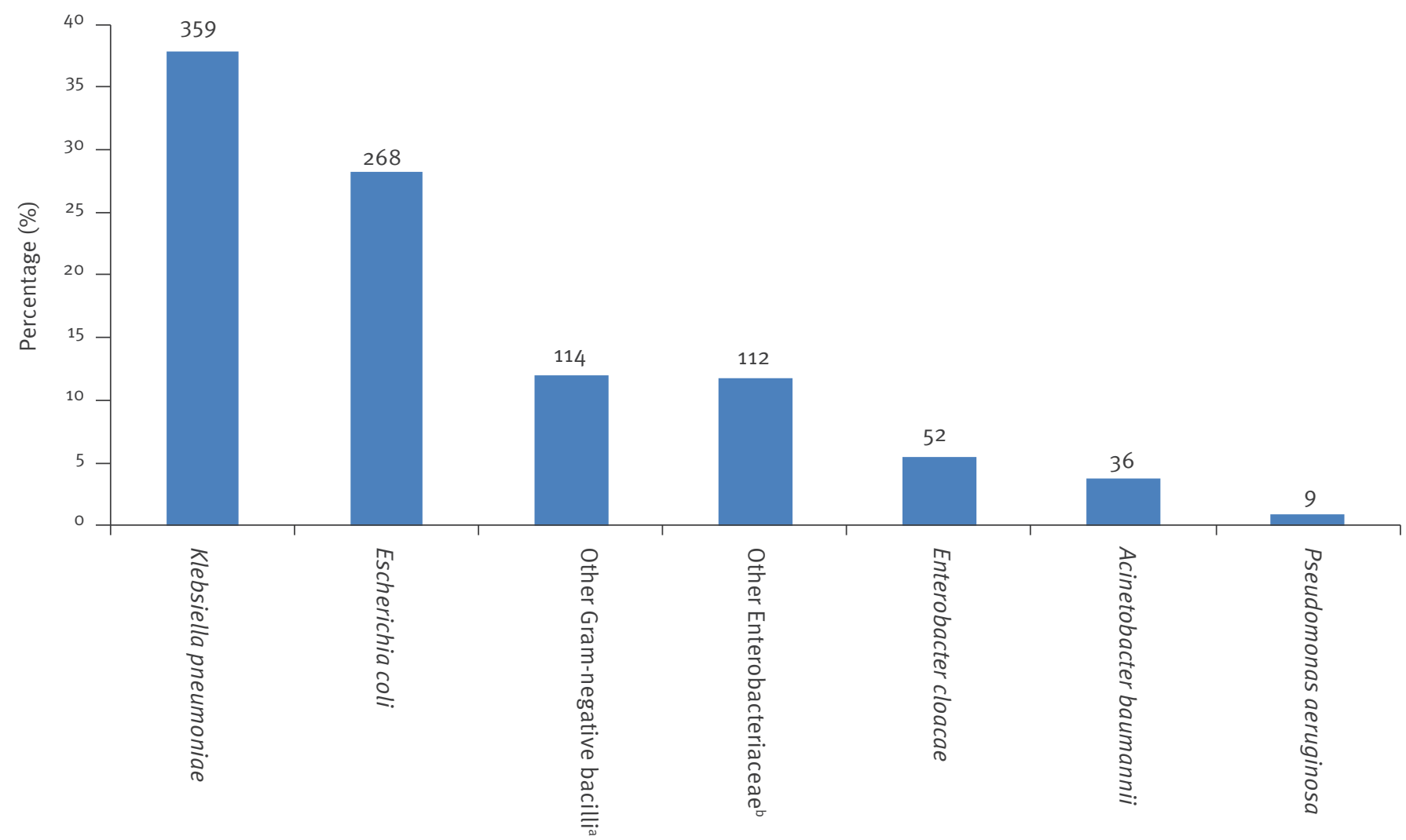

a Acinetobacter pittii $(\mathrm{n}=27)$, Acinetobacter Iwoffii $(\mathrm{n}=20)$, Acinetobacter sp. $(\mathrm{n}=20)$, Pseudomonas aeruginosa $(\mathrm{n}=9)$, Moraxella ssp. $(\mathrm{n}=8)$, Comamonas testosteroni $(\mathrm{n}=7)$, Pseudomonas $\mathrm{sp}$. $(\mathrm{n}=7)$, Stenotrophomonas maltophilia $(\mathrm{n}=5)$, Vibrio cholerae $(\mathrm{n}=3)$, Achromobacter $\mathrm{spp}$. $(\mathrm{n}=2)$, Acinetobacter johnsonii $(\mathrm{n}=2)$, Alcaligenes faecalis $(\mathrm{n}=2)$, Pseudomonas pseudoalcaligenes $(\mathrm{n}=2)$, Pseudomonas putida $(\mathrm{n}=2)$, Acinetobacter junii $(\mathrm{n}=1)$, Acinetobacter ursingii $(\mathrm{n}=1)$, Aeromonas caviae $(\mathrm{n}=1)$, Kingella denitrificans ( $\mathrm{n}=1)$, Methylobacterium spp. $(\mathrm{n}=1)$, Pseudomonas oryzihabitans $(\mathrm{n}=1)$, Suttonella indologenes $(\mathrm{n}=1)$

${ }^{b}$ Citrobacter spp. $(\mathrm{n}=44)$, non-determined Enterobacteriaceae $(\mathrm{n}=15)$, Klebsiella spp. $(\mathrm{n}=10)$, Morganella morganii $(\mathrm{n}=8)$, Enterobacter spp. $(n=7)$, Providencia rettgeri $(n=6)$, Klebsiella oxytoca $(n=5)$, Proteus mirabilis $(n=4)$, Providencia stuartii $(n=3)$, Enterobacter aerogenes $(n=2)$, Proteus spp. $(\mathrm{n}=2)$, Citrobacter braakii $(\mathrm{n}=1)$, Proteus vulgaris $(\mathrm{n}=1)$, Providencia $\mathrm{spp} .(\mathrm{n}=1)$, Salmonella enterica $(\mathrm{n}=1)$, Salmonella spp. $(\mathrm{n}=1)$, Shigella boydii $(\mathrm{n}=1)$

contents on the left-hand side of the screen to access information about the selected article.

Data retrieved were stored and analysed in Excel (Microsoft, Redmond, WA, USA).

\section{Results}

\section{The eReview display}

To visualise the case reports of NDM-1-producing bacteria detected that have appeared around the world since the first description, we developed a Google Maps application as described in the methods section that is regularly updated and freely available on line at the following website: http://www.mediterraneeinfection.com/article.php?laref=318\&titre=new-delhimetallo-lactamase-around-the-world. As soon as an article with the keyword 'NDM-1' or 'New Delhi Metallobeta-lactamase-1' is added to the PubMed database, we automatically receive an alert by email. In less than
10 minutes, we are able to analyse the article, extract the relevant information about the published isolates, add it to our own database and update the map so that the information is freely accessible. Other NDM enzymes are not included in the manuscript but have been added in the Google map website.

\section{Distribution of case reports of New Delhi}

Metallo-beta-lactamase-1-producing bacteria From its first description in 2009 through 31 December 2012, there have been 33 reviews describing the blaNDM-1 gene $[3,11,14,15,19,23-50]$, and 136 case reports in the PubMed database, reporting on 950 isolates of NDM-1-producing bacteria from around the world. There have been 66 articles describing imported human infection isolates with 153 (16.1\%) isolates of NDM-1-producing bacteria; 57 articles describing autochthonous human infection isolates with 571 $(60.1 \%)$ isolates of NDM-1-producing bacteria; and 13 articles describing autochthonous human carriage 
TABLE 1

Bacteria producing New Delhi Metallo-beta-lactamase-1 enzyme reported worldwide by frequency,

1 December 2009 - 31 December 2012 (n=950)

\begin{tabular}{|c|c|c|}
\hline Species & $\begin{array}{l}\text { Number of } \\
\text { isolates }\end{array}$ & $\begin{array}{c}\text { Percentage } \\
\text { of total }\end{array}$ \\
\hline Klebsiella pneumoniae & 359 & 37.8 \\
\hline Escherichia coli & 268 & 28.2 \\
\hline Enterobacter cloacae & 52 & $5 \cdot 5$ \\
\hline Citrobacter spp. & 44 & $4 \cdot 7$ \\
\hline Acinetobacter baumannii & 36 & 3.8 \\
\hline Acinetobacter pittii & 27 & 2.8 \\
\hline Acinetobacter Iwoffii & 20 & 2.1 \\
\hline Acinetobacter sp. & 20 & 2.1 \\
\hline Non-determined Enterobacteriaceae & 15 & 1.6 \\
\hline Klebsiella spp. & 10 & 1.0 \\
\hline Pseudomonas aeruginosa & 9 & 0.9 \\
\hline Moraxella spp. & 8 & 0.8 \\
\hline Morganella morganii & 8 & 0.8 \\
\hline Comamonas testosteroni & 7 & 0.7 \\
\hline Enterobacter spp. & 7 & 0.7 \\
\hline Pseudomonas sp. & 7 & 0.7 \\
\hline Providencia rettgeri & 6 & 0.6 \\
\hline Klebsiella oxytoca & 5 & 0.5 \\
\hline Stenotrophomonas maltophilia & 5 & 0.5 \\
\hline Proteus mirabilis & 4 & 0.4 \\
\hline Providencia stuartii & 3 & 0.3 \\
\hline Vibrio cholerae & 3 & 0.3 \\
\hline Achromobacter spp. & 2 & 0.2 \\
\hline Acinetobacter johnsonii & 2 & 0.2 \\
\hline Alcaligenes faecalis & 2 & 0.2 \\
\hline Enterobacter aerogenes & 2 & 0.2 \\
\hline Proteus spp. & 2 & 0.2 \\
\hline Pseudomonas pseudoalcaligenes & 2 & 0.2 \\
\hline Pseudomonas putida & 2 & 0.2 \\
\hline Acinetobacter junii & 1 & 0.1 \\
\hline Acinetobacter ursingii & 1 & 0.1 \\
\hline Aeromonas caviae & 1 & 0.1 \\
\hline Citrobacter braakii & 1 & 0.1 \\
\hline Kingella denitrificans & 1 & 0.1 \\
\hline Methylobacterium spp. & 1 & 0.1 \\
\hline Proteus vulgaris & 1 & 0.1 \\
\hline Providencia spp. & 1 & 0.1 \\
\hline Pseudomonas oryzihabitans & 1 & 0.1 \\
\hline Salmonella enterica & 1 & 0.1 \\
\hline Salmonella spp. & 1 & 0.1 \\
\hline Shigella boydii & 1 & 0.1 \\
\hline Suttonella indologenes & 1 & 0.1 \\
\hline Total & 950 & 100.0 \\
\hline
\end{tabular}

and environmental case reports, reporting 172 (18.1\%) and $54(5.7 \%)$ isolates of NDM-1-producing bacteria, respectively.

Klebsiella pneumoniae $(\mathrm{n}=359)$ and Escherichia coli $(n=268)$ were the most commonly described NDM-1producing bacteria (Figure 2 ). The bla $a_{\mathrm{NDM}-1}$ gene has also been recorded in Enterobacteriaceae other than K. pneumoniae and E. coli (Table 1); NDM-1-production has been found in clinical Acinetobacter baumannii $(n=36)$, Pseudomonas aeruginosa $(n=9)$ isolates and in a wide variety of non-fermenting Gram-negative species (Table 1).

Distribution of autochthonous case reports of New Delhi Metallo-beta-lactamase -producing bacteria by country

In India, NDM-1-producing bacteria were retrieved from patients in many different cities, including Chennai, Guwahati, Varanasi, Mumbai, Haryana, Kolkata, New Delhi, Pune, Bangalore, and Assam. There have been 374 isolates of NDM-1-producing bacteria responsible for autochthonous human infection $[6,7,51-66] ; 21$ isolates of NDM-1-producing bacteria were responsible for autochthonous human carriage [54,67,68], and 22 isolates of NDM-1-producing bacteria were identified in the environment $[54,69]$. In Pakistan, 32 isolates of NDM-1-producing bacteria were responsible for autochthonous human infection described in nine cities [66, 70], and 101 isolates of NDM-1-producing bacteria were responsible for autochthonous human carriage [70,71]. In China, 16 isolates of NDM-1-producing bacteria were responsible for autochthonous human infection described in eight cities [72-81], 49 isolates of NDM1-producing bacteria were responsible for autochthonous human carriage $[72,82,83]$, and 30 isolates of NDM-1-producing bacteria were identified in the environment [84-86].For the remainder countries, 149 isolates of NDM-1-producing bacteria responsible for autochthonous human infection have been identified in the United Kingdom $(n=23)[59,66]$, Canada $(n=18)$ [8790], Bangladesh $(n=17)[91,92]$, Singapore $(n=15)$ [9395], Israel $(n=10)[96,97]$, Serbia $(n=8)[98,99]$, Kenya $(n=7)$ [10o], Kosovo $(n=7)$ [101], Thailand $(n=6)$ [102], France $(n=4)$ [103-105], Japan $(n=4)$ [106-108], Morocco $(n=4)[109,110]$, South Korea $(n=4)$ [111], Sweden $(n=4)$ [59], Switzerland $(n=3)$ [112], Afghanistan $(n=2)$ [113], Guatemala $(n=2)$ [114], South Africa $(n=2)$ [115], Vietnam $(n=2)$ [116], United Arab Emirates $(n=2)$ [117], Iran $(n=1)$ [118], Mauritius $(n=1)$ [119], Netherlands $(n=1)$ [120], Spain $(n=1)$ [121], and Taiwan $(n=1)$ [122]. Details are included in Figure $3 \mathrm{~A}$. Table 2 summarises the distribution of NDM-1-producing bacteria, grouped according to the type of autochthonous case reports in 29 countries. The year of the first description is indicated for each country. The first NDM-1 producing bacteria causing a human infection was isolated in India in 2006 [6], followed by Kenya in 2007 [100] and the Netherlands in 2008 , the latter a putative secondary transmission [120]. 


\section{TABLE 2}

Distribution of New Delhi Metallo-beta-lactamase-1-producing bacteria reported in autochthonous case reports by country, 1 December 2009-31 December $2012(\mathrm{n}=797)$

\begin{tabular}{|c|c|c|c|c|c|}
\hline $\begin{array}{l}\text { Type of case } \\
\text { reports }\end{array}$ & Country & Cities & $\begin{array}{l}\text { Number of } \\
\text { isolates }\end{array}$ & $\begin{array}{l}\text { First } \\
\text { description }\end{array}$ & References \\
\hline \multirow{28}{*}{$\begin{array}{l}\text { Human } \\
\text { infection }\end{array}$} & Afghanistan & Kabul & 2 & 2011 & [113] \\
\hline & Bangladesh & Dhaka & 17 & 2008 & {$[91,92]$} \\
\hline & Canada & Brampton, Toronto, Winnipeg & 18 & $2009-2010$ & {$[87-90]$} \\
\hline & China & $\begin{array}{l}\text { Beijing, Changsha, Chongqing, Fujian, } \\
\text { Guangzhou, Hangzhou, Hebei, Hong Kong }\end{array}$ & 16 & $2009-2012$ & {$[72-81]$} \\
\hline & France & Bordeaux, Lyon, Toulon & 4 & 2011 & {$[103-105]$} \\
\hline & Guatemala & Not available & 2 & 2011 & {$[114]$} \\
\hline & India & $\begin{array}{l}\text { Assam, Bangalore, Chennai, Guwahati, } \\
\text { Haryana, Kolkata, Mumbai, New Delhi, } \\
\text { Pune, Varanasi }\end{array}$ & 374 & $2006-2007$ & {$[6,7,51,51-66]$} \\
\hline & Iran & Tehran & 1 & 2011 & {$[118]$} \\
\hline & Israel & Jerusalem, Tel Aviv & 10 & 2010 & {$[96,97]$} \\
\hline & Japan & Saitama, Tokyo & 4 & 2010 & {$[106-108]$} \\
\hline & Kenya & Nairobi & 7 & $2007-2009$ & {$[100]$} \\
\hline & Kosovo* & Pristina & 7 & 2010 & {$[101]$} \\
\hline & Mauritius & Quatre Bornes & 1 & 2009 & [119] \\
\hline & Morocco & Rabat, Taza & 4 & 2011 & {$[109,110]$} \\
\hline & The Netherlands & Enschede & 1 & 2008 & {$[120]$} \\
\hline & Pakistan & $\begin{array}{l}\text { Charsadda, Faisalabad, Gujrat, Hafizabad, } \\
\text { Karachi, Khan, Lahore, Rahim Yar, } \\
\text { Sheikhupura }\end{array}$ & 32 & 2009 & {$[66,70]$} \\
\hline & Serbia & Belgrade & 8 & 2010 & {$[98,99]$} \\
\hline & Singapore & Singapore & 15 & 2011 & [93-95] \\
\hline & South Africa & Johannesburg & 2 & 2011 & {$[115]$} \\
\hline & South Korea & Seoul & 4 & 2010 & [111] \\
\hline & Spain & Madrid & 1 & 2012 & {$[121]$} \\
\hline & Sweden & Stockholm & 4 & 2011 & [59] \\
\hline & Switzerland & Geneva & 3 & $2009-2010$ & {$[112]$} \\
\hline & Taiwan & Taipei & 1 & 2011 & [122] \\
\hline & Thailand & Khon Kaen & 6 & 2010 & {$[102]$} \\
\hline & Vietnam & Hanoi & 2 & 2010 & {$[116]$} \\
\hline & United Arab Emirates & Abu Dhabi & 2 & 2011 & {$[117]$} \\
\hline & United Kingdom & 10 cities (not available) & 23 & 2011 & {$[59,66]$} \\
\hline \multirow{4}{*}{$\begin{array}{l}\text { Human } \\
\text { carriage }\end{array}$} & Cameroon & Douala & 1 & 2012 & {$[195]$} \\
\hline & China & Beijing, Changsha & 49 & 2011 & {$[72,82,83]$} \\
\hline & India & Chennai, Guwahati, Kolkata & 21 & 2009 & {$[54,67,68]$} \\
\hline & Pakistan & Rawalpindi & 101 & 2010 & {$[70,71]$} \\
\hline \multirow{3}{*}{$\begin{array}{l}\text { Hospital or } \\
\text { the external } \\
\text { environment }\end{array}$} & China & Beijing, Chengdu & 30 & 2012 & {$[84-86]$} \\
\hline & India & Kolkata, New Delhi & 22 & 2010 & {$[54,69]$} \\
\hline & Vietnam & Hanoi & 2 & 2011 & {$[116]$} \\
\hline
\end{tabular}

* This designation is without prejudice to positions on status, and is in line with UNSCR 1244/99 and the ICJ Opinion on the Kosovo declaration of independence. 
Distribution of imported case reports of New Delhi Metallo beta-lactamase-producing bacteria by country Several imported isolates of NDM-1-producing bacteria have been reported in a number of countries in different geographical locations, but most of them have been reported in the United Kingdom $(n=44)$ [7,123125] (Table 3). The first imported NDM-1-producing bacteria was isolated in 2007 in Germany [126], followed by two isolates in 2008 in the United Kingdom [7] and the Netherlands, respectively [127]. In most of the cases, patients had connections to other countries or regions such as the Indian subcontinent $(n=121)$ $[7,57,104,106,109,123-125,128-162]$, the Balkan $(n=11)$ $[8,112,131,163-168]$, Africa $(n=10)[117,123,160,165,169$ $174]$, the Middle East $(n=6)$ [175-178], and East Asia $(n=5)[179,180]$. The patients originated from these areas, had spent time or been hospitalised there, or they might have been secondarily linked to other hospitalised patients who had recently returned from these areas. Figure $3 \mathrm{~B}$ shows the putative countries of origin for the imported isolates of NDM-1-producing bacteria. The majority of these patients $(61.2 \%)$ had been previously admitted to hospitals in another country because of an accident or an illness that occurred during their travel, although a minority of patients was traveling for medical reasons.

\section{Discussion}

The data presented indicate a worldwide increase in the spread of NDM-1-producing bacteria and other carbapenemase-producing bacteria $[2,7,181]$. In this study, we describe 950 isolates of NDM-1-producing bacteria from different types of case reports in 55 countries between 2006 and 31 December 2012, with the majority of isolates of NDM-1-producing bacteria from India, Pakistan and China. It is probable that the number of published NDM-1-producing bacteria underestimates the true number of cases infected/colonised with NDM-1-producing bacteria because most countries do not perform systematic surveillance for such infections with highly resistant bacteria and many bacteria are not tested for the production of NDM-1 enzyme. In some cases, the patient is asymptomatic, so only colonised. In addition, microbiological guidance on the detection and the identification of carbapenemaseproducing bacteria is only available in a minority of countries, including the European Union [15,41]. The highest concentration of NDM-1-producing bacteria per million square kilometers of land was found between $30^{\circ}$ and $60^{\circ}$ northern latitude, with the main hotspots on the Indian subcontinent and in the Balkan countries. Moreover, the majority of the imported isolates described in our survey using published information to display the geographical occurrence of NDM-1, involved patients with a history of recent travel or hospital admission on the Indian subcontinent or in Balkan countries $[4,7,15]$. In 2008, India and Pakistan received an estimated five million visitors, and an estimated 10 million residents migrated from these countries which amount to a movement and dispersion of 15 million people to third countries [14]. It should be also noted that for some cases travel alone was sufficient to acquire NDM-1-producing bacteria [182].

In view of this situation, we believe that an immediate response to the emergence of NDM-1-producing bacteria and other carbapenemases should be an urgent priority worldwide. At a local level, patients with a history of travel to or originating from high-risk countries or areas should be screened for NDM-1-producing bacteria $[126,127,183,184]$. This screening should prevent the development of onward transmission and potential outbreaks and help to optimise the antibiotic therapy. At the international level, the response to growing multidrug resistance of Gram-negative bacteria should be the implementation of a worldwide surveillance network to discover and report emerging resistance traits [29]. To the best of our knowledge, this study is the first that used Google Maps as an interactive and free tool to document all isolates of NDM-1-producing bacteria worldwide. This tool could be also used to document occurrence and spread of other antibiotic resistance genes. It offers a new way to monitor genes responsible for antibiotic resistance, unlike other works that report on the bacteria responsible for infectious disease. Such a development is important because we are now witnessing outbreaks of resistance genes, not bacteria.

Google Maps can be advantageous to the scientific and medical community for a number of reasons. It facilitates (i) counting the isolates producing antibiotic resistance enzymes, (ii) estimating the prevalence of each bacterial species, (iii) differentiating between different types of case reports, (iv) visualising the relationship between the circulation of antibiotic resistance genes and the worldwide human traffic patterns, (v) identifying the origin and reservoir of the antibiotic resistance gene, and finally (vi) communicating information about the local and worldwide dissemination of antibiotic resistance genes in real time. The advantages of Google Maps also include the immediate access to the PubMed publications from the link in the case report description and the real-time update of the map as soon as an article is added on the PubMed database. Google Maps represents a new generation of interactive review capability; it is easy to use, and it is accessible everywhere by everyone, facilitating the diffusion and the circulation of knowledge.

Simple mapping in public health is not new. The cholera map by John Snow marked a critical turn in the use of maps to understand geographic patterns of disease [185]. Moreover, the geographic distribution of scientific data is a growing area of interest in many fields, including infectious diseases $[20,186]$, paleontology [187], natural products research [22], microbial marine biology [188], ecology [189], and archaeology [190]. It allows the presentation of data (even old data) in new ways. For example, a paper examined the geographic origins of emerging infectious diseases from 1940 to 2004 , showing non-random global patterns 


\section{TABLE 3}

Distribution of New Delhi Metallo-beta-lactamase-1-producing bacteria reported in imported case reports by country, 1 December 2009-31 December $2012(n=153)$

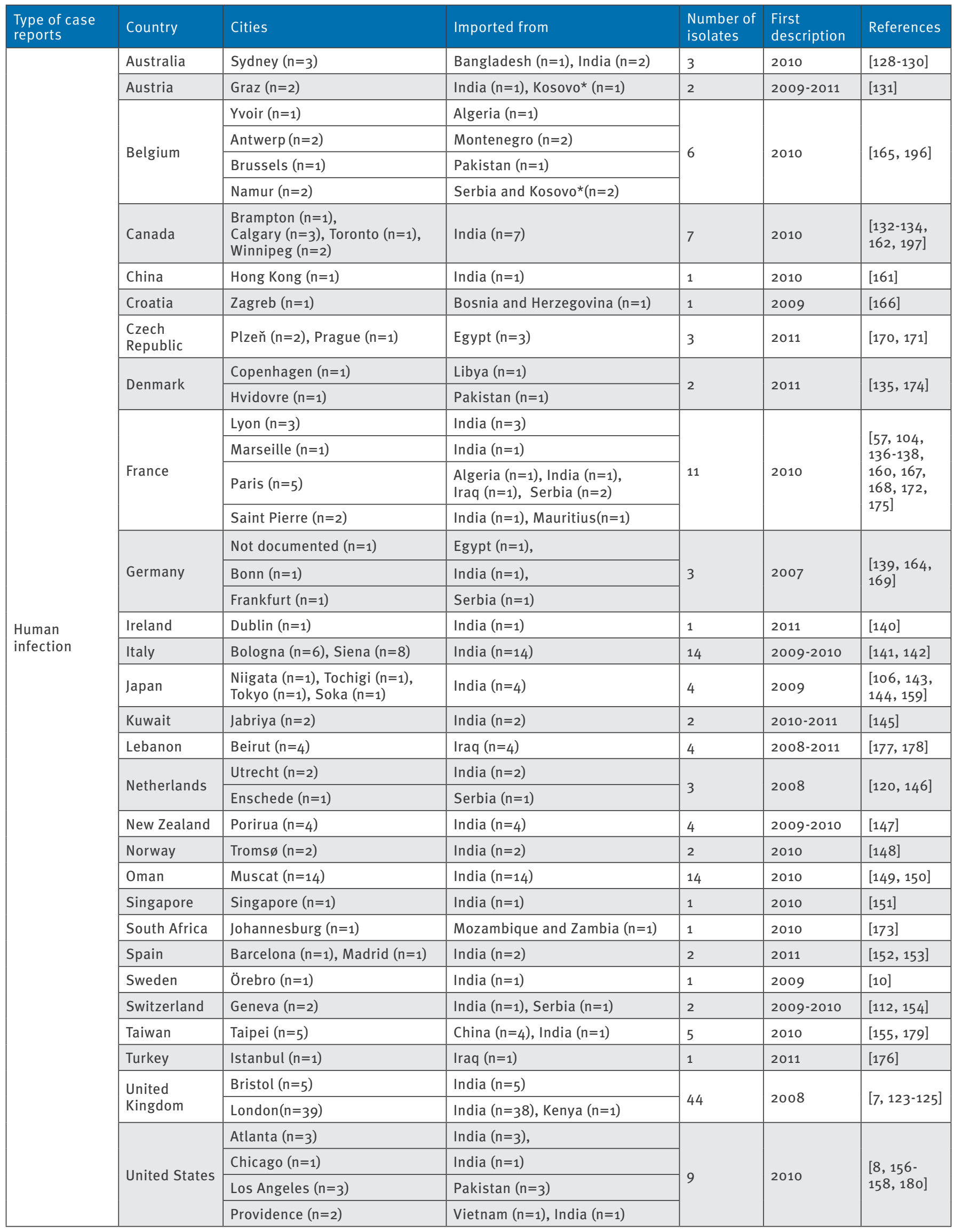

* This designation is without prejudice to positions on status, and is in line with UNSCR $1244 / 99$ and the ICJ Opinion on the Kosovo declaration of independence. 


\section{FIGURE 3}

The worldwide distribution of New Delhi Metallo-beta-lactamase-1-producing bacteria 1 December 2009-31 December 2012 $(\mathrm{n}=950)$

A. Worldwide distribution of autochthonous published isolates carrying the bla $a_{\mathrm{NDM}-1}$ gene

India (52.3\%)

$\square$ Pakistan (16.7\%), China (11.9\%)

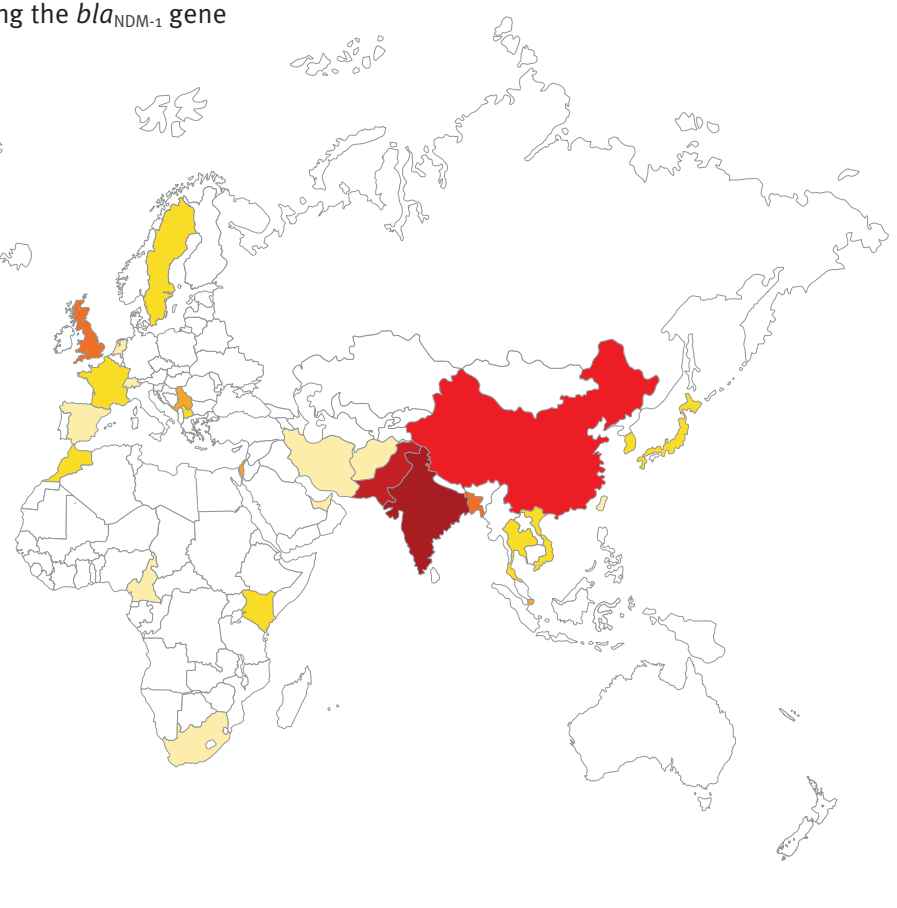

$\square$ United Kingdom (2.9\%), Canada (2.3\%), Bangladesh (2.1\%)

$\square$ Singapore (1.9\%), Israel (1.2\%), Serbia (1.0\%)

$\square$ Kenya (0.9\%), Kosovo* (0.9\%), Thailand (0.7 \%), France (0.5\%), Japan (0.5\%), Morocco (0.5 \%), South Korea (0.5\%), Sweden (0.5\%), Vietnam (0.5\%)

$\square$ Switzerland (0.4\%), Afghanistan (0.2\%), Guatemala (0.2 \%), South Africa (0.2 \%), United Arab Emirates (0.2 \%), Iran (0.1\%), Mauritius (0.1\%),

The Netherlands $(0.1 \%)$, Spain (0.1\%), Taiwan (0.1\%), Cameroon (0.1\%)

B. Putative countries of origin for imported published isolates carrying the bla $a_{\mathrm{NDM}-1}$ gene

India $(75.2 \%)$

$\square$ Serbia (3.9\%), Iraq (3.9\%), Pakistan (3.3\%)

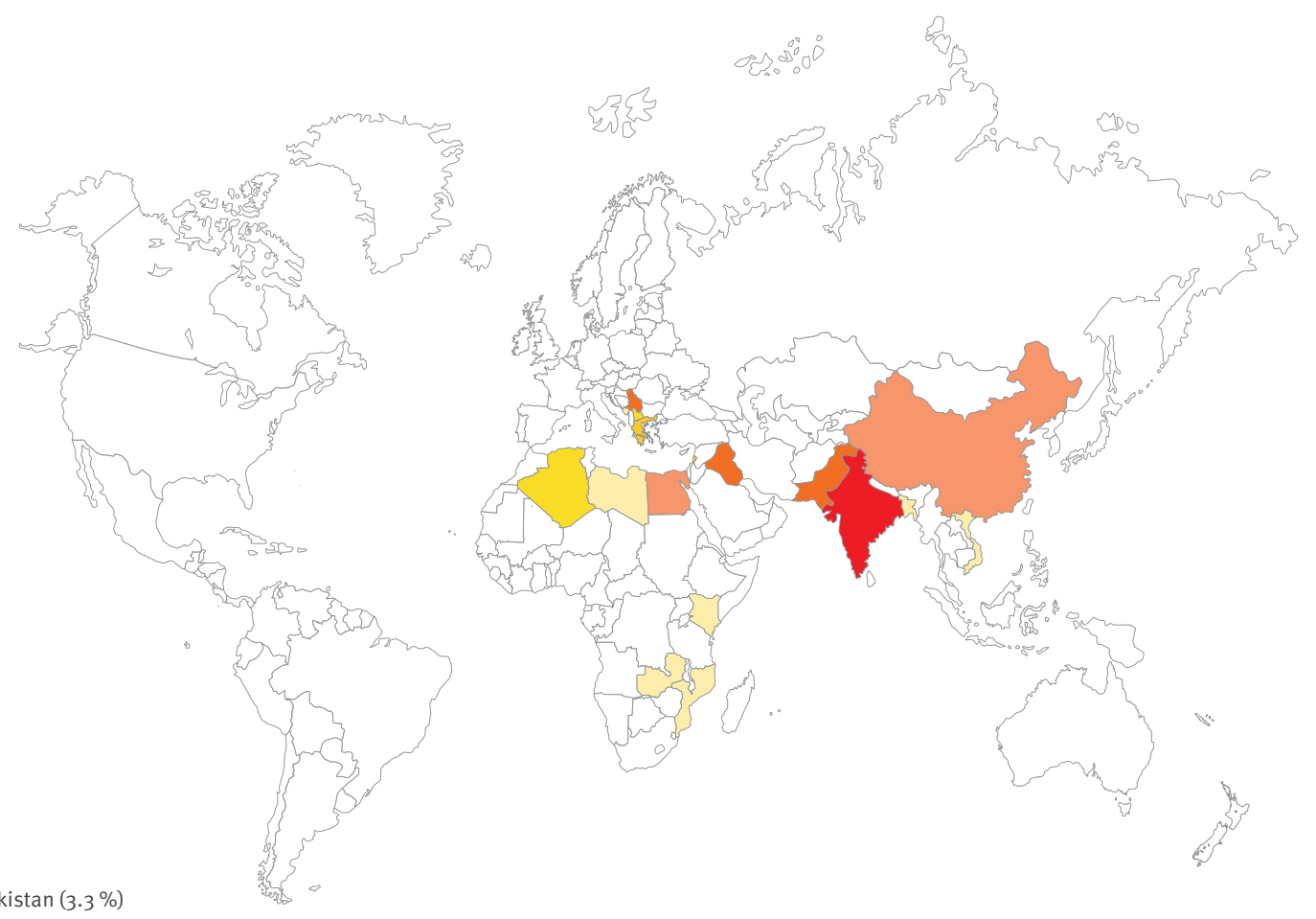

$\square$ Egypt (2.6\%), China (2.6\%)

$\square$ Algeria (1.3\%), Kosovo* (1.3\%), Montenegro (1.3\%)

$\square$ Bangladesh (0.6\%), Kenya (o.6 \%), Bosnia and Herzegovina (o.6 \%), Mozambique and Zambia (0.6\%), Vietnam (o.6 \%), Libya (o.6 \%), Mauritius (o.6 \%)

* This designation is without prejudice to positions on status, and is in line with UNSCR $1244 / 99$ and the ICJ Opinion on the Kosovo declaration of independence.

NDM-1: New Delhi Metallo-beta-lactamase-1 
[191]. Another online, real-time disease outbreak monitoring system, 'HealthMap', developed by the John Brownstein and his team in 2008, has demonstrated the effectiveness of collecting new media sources for improved situational awareness of infectious disease worldwide [192].

Given the popularity of Google Maps, it can be expected that Google will continue to add new features, such as higher resolution, more options for the maps, threedimensional views, and a Smartphone application. Smartphone applications are a growing field that offers novel approaches, with software that allows data entry and retrieval of data from the maps using a mobile phone [193,194]. The possibilities are vast and for all those interested to better convey information we propose to keep an open mind and test different visual representations. We strongly encourage epidemiologists to embrace new types data collection by using interactive tools for surveillance purposes and perhaps more importantly to communicate these data to other members of the research community and the general public in real time. Using detailed maps to convey such data visually helps to break down communication barriers and bring diverse research ideas together [22].

\section{Conflict of interest}

None declared.

\section{Authors' contributions}

$M B, S M D, L M, P P, M D, D R$, and JMR analysed the data, and wrote the manuscript. MB and SMD collect the data and build the map.

\section{References}

1. Walsh TR, Toleman MA, Poirel L, Nordmann P. Metallo beta-lactamases: the quiet before the storm? Clin Microbio Rev. 2005;18(2):306-25. http://dx.doi.org/10.1128/ CMR.18.2.306-325.2005

2. Queenan AM, Bush K. Carbapenemases: the versatile betalactamases. Clin Microbiol Rev. 2007;20(3):440-58, table of contents.

http://dx.doi.org/10.1128/CMR.00001-07

3. Cornaglia G, Giamarellou H, Rossolini GM. Metallo-betalactamases: a last frontier for beta-lactams? Lancet Infect Dis. 2011;11(5):381-93. http://dx.doi.org/10.1016/ S1473-3099(11)70056-1

4. Krishna BV. New Delhi metallo-beta-lactamases: a wake-up call for microbiologists. Indian J Med Microbiol. 2010;28(3):265-6. http://dx.doi.org/10.4103/0255-0857.66477

5. Muir A, Weinbren MJ. New Delhi metallo-beta-lactamase: a cautionary tale. J Hosp Infect. 2010;75(3):239-40. http://dx.doi.org/10.1016/j.jhin.2010.02.005

6. Castanheira M, Deshpande LM, Mathai D, Bell JM, Jones RN, Mendes RE. Early dissemination of NDM-1- and OXA 181-producing Enterobacteriaceae in Indian hospitals: report from the SENTRY antimicrobial surveillance program, 2006-2007. Antimicrob Agents Chemother 2011;55(3):1274-8. http://dx.doi.org/10.1128/AAC.01497-10

7. Kumarasamy KK, Toleman MA, Walsh TR, Bagaria J, Butt $\mathrm{F}$, Balakrishnan R et al. Emergence of a new antibiotic resistance mechanism in India, Pakistan, and the UK: a molecular, biological, and epidemiological study. Lancet Infect Dis. 2010;10(9):597-602.

http://dx.doi.org/10.1016/S1473-3099(10)70143-2
8. Mochon AB, Garner OB, Hindler JA, Krogstad P, Ward KW, Lewinski MA et al. New Delhi metallo-beta-lactamase (NDM-1)-producing Klebsiella pneumoniae: case report and laboratory detection strategies. J Clin Microbiol. 2011;49(4):1667-70. http://dx.doi.org/10.1128/JCM.00183-11

9. Sekizuka T, Matsui M, Yamane K, Takeuchi F, Ohnishi M, Hishinuma A et al. Complete sequencing of the bla(NDM-1)positive IncA/C plasmid from Escherichia coli ST38 isolate suggests a possible origin from plant pathogens. PLoS One. 2011;6(9):e25334. http://dx.doi.org/10.1371/journal.pone.0025334

10. Yong D, Toleman MA, Giske CG, Cho HS, Sundman K, Lee $\mathrm{K}$ et al. Characterization of a new metallo-beta-lactamase gene, bla(NDM-1), and a novel erythromycin esterase gene carried on a unique genetic structure in Klebsiella pneumoniae sequence type 14 from India. Antimicrob Agents Chemother. 2009;53(12):5046-54. http://dx.doi. org/10.1128/AAC.00774-09

11. Khan AU, Nordmann P. Spread of carbapenemase NDM1 producers: The situation in India and what may be proposed. Scand J Infect Dis 2012;44(7):531-5. http:// dx.doi.org/10.3109/00365548.2012.669046

12. Livermore DM, Walsh TR, Toleman M, Woodford N. Balkan NDM-1: escape or transplant? Lancet Infect Dis. 2011(3);11:164.

http://dx.doi.org/10.1016/S1473-3099(11)70048-2

13. Nordmann P, Poirel L, Walsh TR, Livermore DM. The emerging NDM carbapenemases. Trends Microbiol 2011;19(12):588-95

http://dx.doi.org/10.1016/j.tim.2011.09.005

14. Nordmann P, Poirel L, Toleman MA, Walsh TR. Does broad spectrum beta-lactam resistance due to NDM-1 herald the end of the antibiotic era for treatment of infections caused by Gram-negative bacteria? J Antimicrob Chemother. 2011;66(4):689-92.

http://dx.doi.org/10.1093/jac/dkq520

15. Wilson ME, Chen LH. NDM-1 and the role of travel in its dissemination. Curr Infect Dis Rep. 2012;14(3):213-26. http://dx.doi.org/10.1007/s11908-012-0252-x

16. Poirel L, Hombrouck-Alet C, Freneaux C, Bernabeu S, Nordmann P. Global spread of New Delhi metallo-betalactamase 1. Lancet Infect Dis. 2010;10(12):832. http:// dx.doi.org/10.1016/S1473-3099(10)70279-6

17. Chen LH, Wilson ME. The role of the traveler in emerging infections and magnitude of travel. Med Clin North Am. 2008;92(6):1409-32, xi. http://dx.doi.org/10.1016/j. mcna.2008.07.005

18. Reed CM. Medical tourism. Med Clin North Am 2008;92(6):1433-46, xi. http://dx.doi.org/10.1016/j.mcna.2008.08.001

19. Walsh TR, Toleman MA. The emergence of pan-resistant Gram-negative pathogens merits a rapid global political response. J Antimicrob Chemother. 2012;67(1):1-3. http:// dx.doi.org/10.1093/jac/dkr378

20. Brownstein JS, Freifeld CC, Chan EH, Keller M, Sonricker AL, Mekaru SR et al. Information technology and global surveillance of cases of $2009 \mathrm{H}_{1} \mathrm{~N}_{1}$ influenza. N Engl J Med. 2010;362(18):1731-5. http://dx.doi.org/10.1056/ NEJMsr1002707

21. Hoen AG, Keller M, Verma AD, Buckeridge DL, Brownstein JS. Electronic event-based surveillance for monitoring dengue, Latin America. Emerg Infect Dis. 2012;18(7):114750. http://dx.doi.org/10.3201/eid1807.120055 http:// dx.doi.org/10.3201/eid1808.120055

22. Oberlies NH, Rineer JI, Alali FQ, Tawaha K, Falkinham JO 3rd, Wheaton WD. Mapping of Sample Collection Data: GIS Tools for the Natural Product Researcher. Phytochem Lett. 2009;2(1):1-9. http://dx.doi.org/10.1016/j.phytol.2008.10.006

23. Charan J, Mulla S, Ryavanki S, Kantharia N. New Delhi Metallo - beta lactamase - 1 containing Enterobacteriaceae: origin, diagnosis, treatment and public health concern. Pan Afr Med J. 2012;11:22.

24. Patel S. NDM-1: The newest superbug? Nursing. 2012;42(2):67-8.

http://dx.doi.org/10.1097/01.NURSE.0000412934.58501.8c

25. Doi Y. [Antimicrobial resistance testing in clinical practice.] Nihon Rinsho 2012;70(2):272-5. Japanese.

26. Kirby T. Timothy Walsh: introducing the world to NDM-1. Lancet Infect Dis. 2012;12(3):189.

http://dx.doi.org/10.1016/S1473-3099(12)70044-0

27. Pittalis S, Ferarro F, Puro V. [NDM-1: the superbug?] Infez Med. 2011;19(4):224-34. Italian. 
28. Matsumoto T. [The cutting-edge of medicine; Microbiological and clinical approach to multidrug resistant bacteria, such as multidrug-resistant Pseudomonas aeruginosa, multidrug-resistant Acinetobacter, NDM-1 producing bacteria.] Nihon Naika Gakkai Zasshi. 2011;100(10):3072-8. Japanese. http:/l dx.doi.org/10.2169/naika.100.3072 http://dx.doi. org/10.2169/naika.100.2924

29. Nordmann P, Poirel L, Walsh TR, Livermore DM. The emerging NDM carbapenemases. Trends Microbiol. 2011;19(2):588-95. http://dx.doi.org/10.1016/j.tim.2011.09.005

30. Shakil S, Azhar El, Tabrez S, Kamal MA, Jabir NR, Abuzenadah AM et al. New Delhi metallo-beta-lactamase (NDM-1): an update. J Chemother. 2011;23(5):263-5. http:// dx.doi.org/10.1179/joc.2011.23.5.263

31. Nicolle LE. Update in adult urinary tract infection. Curr Infect Dis Rep. 2011;13(6):552-60. http://dx.doi.org/10.1007/s11908-011-0212-x

32. Biondi S, Long S, Panunzio M, Qin WL. Current trends in beta-lactam based beta-lactamases inhibitors. Curr Med Chem. 2011;18(27):4223-36. http://dx.doi. org/10.2174/092986711797189655

33. Walsh TR. New Delhi metallo-beta-lactamase-1: detection and prevention. CMAJ. 2011;183(11):1240-1. http://dx.doi.org/10.1503/cmaj.111100

34. Bush K, Fisher JF. Epidemiological expansion, structural studies, and clinical challenges of new betalactamases from gram-negative bacteria. Annu Rev Microbiol. 2011;65:455-78. http://dx.doi.org/10.1146/ annurev-micro-090110-102911

35. Sun HM, Xue GH. [Epidemiology and antibiotic resistance mechanisms of newly discovered "super bacteria containing NDM-1"]. Zhonghua Er Ke Za Zhi 2011;49(1):3740. Chinese.

36. Jean SS, Hsueh PR. High burden of antimicrobial resistance in Asia. Int J Antimicrob Agents. 2011;37(4):291-5. http://dx.doi.org/10.1016/j.ijantimicag.2011.01.009

37. Kalan L, Wright GD. Antibiotic adjuvants: multicomponent anti-infective strategies. Expert Rev Mol Med. 2011;13:e5 http://dx.doi.org/10.1017/S1462399410001766

38. Sun M, Zheng B, Gao GF, Zhu B. [Arms racing between human beings and pathogens: NDM-1 and superbugs. Sheng Wu Gong Cheng Xue Bao. 2010;26(11):1461-72. Chinese.

39. Arya SC, Agarwal N. International travel with acquisition of multi-drug resistant Gram negative bacteria containing the New Delhi metallo-beta-lactamase gene, bla NDM-1. Travel Med Infect Dis. 2011;9(1):47-8. http://dx.doi.org/10.1016/j. tmaid.2010.12.002

40. Raghunath D. New metallo beta-lactamase NDM-1. Indian J Med Res. 2010;132:478-81.

41. Struelens MJ, Monnet DL, Magiorakos AP, Santos OF, Giesecke J. New Delhi metallo-beta-lactamase 1-producing Enterobacteriaceae: emergence and response in Europe. Euro Surveill 2010;15(46)pii: 19716.

42. Walsh TR. Emerging carbapenemases: a globa perspective. Int J Antimicrob Agents. 2010;36 Suppl 3:S8http://dx.doi.org/10.1016/So924-8579(10)70004-2

43. Nordmann P. [Gram-negative bacteria with resistance to carbapenems.] Med Sci (Paris). 2010;26(11):950-9. French. http://dx.doi.org/10.1051/medsci/20102611950

44. Deshpande P, Shetty A, Kapadia F, Hedge A, Soman R, Rodrigues C. New Delhi metallo 1: have carbapenems met their doom? Clin Infect Dis. 2010;51(10):1222. http://dx.doi. org/10.1086/656921

45. Park A. Antibiotics. NDM-1 how dangerous is the mutation? Time. 2010;176(14):20.

46. Bush K. Alarming beta-lactamase-mediated resistance in multidrug-resistant Enterobacteriaceae. Curr Opin Microbiol. 2010;13(5):558-64. http://dx.doi.org/10.1016/j. mib.2010.09.006

47. El-Herte RI, Kanj SS, Matar GM, Araj GF. The threat of carbapenem-resistant Enterobacteriaceae in Lebanon: An update on the regional and local epidemiology. J Infect Public Health. 2012;5(3):233-43. http://dx.doi. org/10.1016/j.jiph.2012.02.003

48. Wachino J, Arakawa Y. Exogenously acquired $16 \mathrm{~S}$ rRNA methyltransferases found in aminoglycoside-resistant pathogenic Gram-negative bacteria: An update. Drug Resist Updat. 2012;15(3):133-48.

49. Tateda K. [Antibiotic-resistant bacteria and new directions of antimicrobial chemotherapy.] Rinsho Byori 2012;60(5):443-8. Japanese.
50. Li Y, Xiang Q, Zhang Q, Huang Y, Su Z. Overview on the recent study of antimicrobial peptides: origins, functions, relative mechanisms and application. Peptides. 2012;37(2):207-15.

http://dx.doi.org/10.1016/j.peptides.2012.07.001

51. Seema K, Ranjan SM, Upadhyay S, Bhattacharjee A. Dissemination of the New Delhi metallo-beta-lactamase-1 (NDM-1) among Enterobacteriaceae in a tertiary referral hospital in north India. J Antimicrob Chemother. 2011;66(7):1646-7. http://dx.doi.org/10.1093/jac/dkr18o

52. Sowmiya M, Umashankar V, Muthukumaran S, Madhavan HN, Malathi J. Studies on New Delhi Metallo-BetaLactamse-1 producing Acinetobacter baumannii isolated from donor swab in a tertiary eye care centre, India and structural analysis of its antibiotic binding interactions. Bioinformation. 2012;8(10):445-52. http://dx.doi.org/10.6026/97320630008445

53. Castanheira M, Deshpande LM, Farrell SE, Shetye S, Shah N, Jones RN. Update on the prevalence and genetic characterization of NDM-1-producing Enterobacteriaceae in Indian hospitals during 2010. Diagn Microbiol Infect Dis. 2013;75(2):210-3. http://dx.doi.org/10.1016/j.diagmicrobio.2012.10.017

54. Roy S, Singh AK, Viswanathan R, Nandy RK, Basu S. Transmission of imipenem resistance determinants during the course of an outbreak of NDM-1 Escherichia coli in a sick newborn care unit. J Antimicrob Chemother. 2011;66(12):2773-80 http://dx.doi.org/10.1093/jac/dkr376

55. Karthikeyan K, Thirunarayan MA, Krishnan P. Coexistence of blaOXA-23 with blaNDM-1 and armA in clinical isolates of Acinetobacter baumannii from India. J Antimicrob Chemother. 2010;65(10):2253-4 http://dx.doi.org/10.1093/jac/dkq273

56. Deshpande P, Rodrigues C, Shetty A, Kapadia F, Hedge A, Soman R. New Delhi Metallo-beta lactamase (NDM-1) in Enterobacteriaceae: treatment options with carbapenems compromised. J Assoc Physicians India. 2010;58:147-9.

57. Poirel L, Dortet L, Bernabeu S, Nordmann P. Genetic features of blaNDM-1-positive Enterobacteriaceae. Antimicrob Agents Chemother. 2011;55(11):5403-7. http://dx.doi.org/10.1128/AAC.00585-11

58. Choudhury SR, Roy S, Goswami A, Basu S. Polyethylene glycol-stabilized sulphur nanoparticles: an effective antimicrobial agent against multidrug-resistant bacteria. Antimicrob Chemother. 2012;67(5):1134-7. http://dx.doi.org/10.1093/jac/dkr591

59. Giske CG, Fröding I, Hasan CM, Turlej-Rogacka A, Toleman $M$, Livermore D, et al. Diverse sequence types of Klebsiella pneumoniae contribute to the dissemination of blaNDM-1 in India, Sweden, and the United Kingdom. Antimicrob Agents Chemother. 2012;56(5):2735-8. http://dx.doi.org/10.1128/AAC.06142-11

6o. Roy S, Viswanathan R, Singh AK, Das P, Basu S. Sepsis in neonates due to imipenem-resistant Klebsiella pneumoniae producing NDM-1 in India. J Antimicrob Chemother. 2011;66(6):1411-3. http://dx.doi.org/10.1093/jac/dkro68

61. Nordmann P, Boulanger AE, Poirel L. NDM-4 metallo beta-lactamase with increased carbapenemase activity from Escherichia coli. Antimicrob Agents Chemother. 2012;56(4):2184-6. http://dx.doi.org/10.1128/AAC.05961-11

62. Bharadwaj R, Joshi S, Dohe V, Gaikwad V, Kulkarni G, Shouche Y. Prevalence of New Delhi metallo-betalactamase (NDM-1)-positive bacteria in a tertiary care centre in Pune, India. Int J Antimicrob Agents. 2012;39(3):265-6. http://dx.doi.org/10.1016/j.ijantimicag.2011.09.027

63. Khan AU, Nordmann P. NDM-1-producing Enterobacter cloacae and Klebsiella pneumoniae from diabetic foot ulcers in India. J Med Microbiol. 2012;61(Pt 3):454-6. http://dx.doi.org/10.1099/jmm.0.039008-0

64. Kumarasamy K, Kalyanasundaram A. Emergence of Klebsiella pneumoniae isolate co-producing NDM-1 with KPC-2 from India. J Antimicrob Chemother. 2012;67(1):243 http://dx.doi.org/10.1093/jac/dkr431

65. Lascols C, Hackel M, Marshall SH, Hujer AM, Bouchillon $S$, Badal $R$ et al. Increasing prevalence and dissemination of NDM-1 metallo-beta-lactamase in India: data from the SMART study (2009). J Antimicrob Chemother. 2011;66(9):1992-7. http://dx.doi.org/10.1093/jac/dkr240

66. Mushtaq S, Irfan S, Sarma JB, Doumith M, Pike R, Pitout J et al. Phylogenetic diversity of Escherichia coli strains 
producing NDM-type carbapenemases. J Antimicrob Chemother. 2011;66(9):2002-5.

http://dx.doi.org/10.1093/jac/dkr226

67. Murali S, Jambulingam M, Tiru V, Kulanthai LT, Rajagopal $\mathrm{R}$, Padmanaban $\mathrm{P}$, et al. A study on isolation rate and prevalence of drug resistance among microorganisms isolated from multiorgan donor and donor corneal rim along with a report on existence of bla NDM-1 among Indian population. Curr Eye Res. 2012;37(3):195-203. http://dx.doi.org/10.3109/02713683.2011.643270

68. Sarma JB, Bhattacharya PK, Kalita D, Rajbangshi M. Multidrug-resistant Enterobacteriaceae including metallobeta-lactamase producers are predominant pathogens of healthcare-associated infections in an Indian teaching hospital. Indian J Med Microbiol. 2011;29(1):22-7. http://dx.doi.org/10.4103/0255-0857.76519

69. Walsh TR, Weeks J, Livermore DM, Toleman MA. Dissemination of NDM-1 positive bacteria in the New Delhi environment and its implications for human health: an environmental point prevalence study. Lancet Infect Dis. 2011;11(5):355-62. http://dx.doi.org/10.1016/S1473-3099(11)70059-7

70. Perry JD, Naqvi SH, Mirza IA, Alizai SA, Hussain A, Ghirardi $S$, et al. Prevalence of faecal carriage of Enterobacteriaceae with NDM-1 carbapenemase at military hospitals in Pakistan, and evaluation of two chromogenic media. J Antimicrob Chemother. 2011;66(10):2288-94 http://dx.doi.org/10.1093/jac/dkr299

71. Day KM, Ali S, Mirza IA, Sidjabat HE, Silvey A, Lanyon CV, et al. Prevalence and molecular characterization of Enterobacteriaceae producing NDM-1 carbapenemase at a military hospital in Pakistan and evaluation of two chromogenic media. Diagn Microbiol Infect Dis. 2013;75(2):187-91. http://dx.doi.org/10.1016/j.diagmicrobio.2012.11.006

72. Ho PL, Li Z, Lai EL, Chiu SS, Cheng VC. Emergence of NDM 1-producing Enterobacteriaceae in China. J Antimicrob Chemother. 2012;67(6):1553-5. http://dx.doi.org/10.1093/jac/dkso95

73. Hu Y, Zhang W, Liang H, Liu L, Peng G, Pan Y, et al. Whole genome sequence of a multidrug-resistant clinical isolate of Acinetobacter lwoffii. J Bacteriol. 2011;193(19):5549-50. http://dx.doi.org/10.1128/JB.05617-11

74. Zhou Z, Guan R, Yang Y, Chen L, Fu J, Deng Q et al. Identification of New Delhi metallo-beta-lactamase gene (NDM-1) from a clinical isolate of Acinetobacter junii in China. Can J Microbiol. 2012;58(1):112-5. http://dx.doi.org/10.1139/w11-112

75. Hu H, Hu Y, Pan Y, Liang $\mathrm{H}$, Wang $\mathrm{H}$, Wang X, et al. Novel plasmid and its variant harboring both a bla(NDM-1) gene and type IV secretion system in clinical isolates of Acinetobacter lwoffii. Antimicrob Agents Chemother. 2012;56(4):1698-702. http://dx.doi.org/10.1128/AAC.06199-11

76. Ho PL, Lo WU, Yeung MK, Lin CH, Chow KH, Ang I et al. Complete sequencing of pNDM-HK encoding NDM-1 carbapenemase from a multidrug-resistant Escherichia coli strain isolated in Hong Kong. PLoS One. 2011;6(3):e17989. http://dx.doi.org/10.1371/journal.pone.0017989

77. Liu W, Zou D, Li Y, Wang X, He X, Wei X et al. Sensitive and rapid detection of the new delhi metallo-Beta-lactamase gene by loop-mediated isothermal amplification. J Clin Microbiol. 2012;50:1580-5. http://dx.doi.org/10.1128/JCM.06647-11

78. Chen Y, Zhou Z, Jiang Y, Yu Y. Emergence of NDM-1 producing Acinetobacter baumannii in China. J Antimicrob Chemother. 2011;66(6):1255-9. http://dx.doi.org/10.1093/jac/dkro82

79. Zou MX, Wu JM, Li J, Dou QY, Zhou RR, Huang Y et al. NDM1-producing Klebsiella pneumoniae in mainland China. Zhongguo Dang Dai Er Ke Za Zhi. 2012;14(8):616-21.

80. Huang S, Dai W, Sun S, Zhang X, Zhang L. Prevalence of plasmid-mediated quinolone resistance and aminoglycoside resistance determinants among carbapeneme non-susceptible Enterobacter cloacae. PLoS One. 2012;7(10):e47636 http://dx.doi.org/10.1371/journal.pone.0047636

81. Dai W, Sun S, Yang P, Huang S, Zhang X, Zhang L. Characterization of carbapenemases, extended spectrum beta-lactamases and molecular epidemiology of carbapenem-non-susceptible Enterobacter cloacae in a Chinese hospital in Chongqing. Infect Genet Evol . 2013;14:1-7. http://dx.doi.org/10.1016/j.meegid.2012.10.010

82. Fu Y, Du X, Ji J, Chen Y, Jiang Y, Yu Y. Epidemiological characteristics and genetic structure of blaNDM-1 in non-baumannii Acinetobacter spp. in China. J Antimicrob Chemother. 2012;67(9):2114-22 http://dx.doi.org/10.1093/jac/dks192

83. Wang X, Liu W, Zou D, Li X, Wei X, Shang W et al. High rate of New Delhi metallo-beta-lactamase 1-producing bacterial infection in China. Clin Infect Dis. 2013;56(1):161-2. http://dx.doi.org/10.1093/cid/cis782

84. Wang Y, Wu C, Zhang Q, Qi J, Liu H, Wang Y, et al. Identification of New Delhi Metallo-beta-lactamase 1 in Acinetobacter lwoffii of food animal origin. PLoS One. 2012;7(5):e37152. http://dx.doi.org/10.1371/journal.pone.0037152

85. Yang J, Chen Y, Jia X, Luo Y, Song Q, Zhao W, et al. Dissemination and characterization of NDM-1-producing Acinetobacter pittii in an intensive care unit in China. Clin Microbiol Infect. 2012;18(12):E506-13.

86. Zong Z, Zhang X. blaNDM-1-carrying Acinetobacter johnsonii detected in hospital sewage. J Antimicrob Chemother. 2013;68(5):1007-10. http://dx.doi.org/10.1093/jac/dks505

87. Kus JV, Tadros M, Simor A, Low DE, McGeer AJ, Willey $B M$, et al. New Delhi metallo-beta-lactamase-1: loca acquisition in Ontario, Canada, and challenges in detection. CMAJ. 2011;183(11):1257-61. http://dx.doi.org/10.1503/cmaj.110477

88. Mataseje LF, Bryce E, Roscoe D, Boyd DA, Embree J, Gravel $D$, et al. Carbapenem-resistant Gram-negative bacilli in Canada 2009-10: results from the Canadian Nosocomial Infection Surveillance Program (CNISP). J Antimicrob Chemother. 2012;67(6):1359-67. http://dx.doi.org/10.1093/jac/dkso46

89. Lowe CF, Kus JV, Salt N, Callery S, Louie L, Khan MA, et al. Nosocomial transmission of New Delhi metallo-betaactamase-1-producing Klebsiella pneumoniae in Toronto, Canada. Infect Control Hosp Epidemiol. 2013;34(1):49-55. http://dx.doi.org/10.1086/668778

90. Borgia S, Lastovetska O, Richardson D, Eshaghi A, Xiong J, Chung C, et al. Outbreak of carbapenem-resistant enterobacteriaceae containing blaNDM-1, Ontario, Canada. Clin Infect Dis. 2012;55(11):e109-17. http://dx.doi.org/10.1093/cid/cis737

91. Islam MA, Talukdar PK, Hoque A, Huq M, Nabi A, Ahmed D, et al. Emergence of multidrug-resistant NDM-1-producing Gram-negative bacteria in Bangladesh. Eur J Clin Microbiol Infect Dis. 2012;31(10):2593-600. http://dx.doi.org/10.1007/s10096-012-1601-2

92. Islam MA, Huq M, Nabi A, Talukdar PK, Ahmed D, Talukder $K A$, et al. Occurrence and characterization of multidrugresistant New Delhi metallo-beta-lactamase-1-producing bacteria isolated between 2003 and 2010 in Bangladesh. Med Microbiol. 2013;62(Pt 1):62-8. http://dx.doi.org/10.1099/jmm.0.048066-0

93. Chien JM, Koh TH, Chan KS, Chuah TH, Tan TT. Successful treatment of NDM-1 Klebsiella pneumoniae bacteraemia in a neutropenic patient. Scand J Infect Dis. 2012;44(4):312-4. http://dx.doi.org/10.3109/00365548.2011.633549

94. Ong DC, Koh TH, Syahidah N, Krishnan P, Tan TY. Rapid detection of the blaNDM-1 gene by real-time PCR. Antimicrob Chemother. 2011;66(7):1647-9. http://dx.doi.org/10.1093/jac/dkr184

95. Chen YT, Lin AC, Siu LK, Koh TH. Sequence of closely related plasmids encoding bla(NDM-1) in two unrelated Klebsiella pneumoniae isolates in Singapore. PLoS One. 2012;7:e48737 http://dx.doi.org/10.1371/journal.pone.0048737

96. Espinal P, Fugazza G, Lopez Y, Kasma M, Lerman Y, Malhotra-Kumar S, et al. Dissemination of an NDM-2producing Acinetobacter baumannii clone in an Israeli rehabilitation center. Antimicrob Agents Chemother. 2011;55(11):5396-8. http://dx.doi.org/10.1128/AAC.00679-11

97. Lachish T, Elimelech M, Arieli N, Adler A, Rolain JM, Assous MV. Emergence of New Delhi metallo-beta-lactamase in Jerusalem, Israel. Int J Antimicrob Agents. 2012;40(6):566http://dx.doi.org/10.1016/j.ijantimicag.2012.07.011

98. Jovcic B, Lepsanovic Z, Suljagic V, Rackov G, Begovic , Topisirovic L, et al. Emergence of NDM-1 metallobeta-lactamase in Pseudomonas aeruginosa clinical isolates from Serbia. Antimicrob Agents Chemother. 2011;55(8):3929-31. http://dx.doi.org/10.1128/AAC.00226-11

99. Mirovic V, Tomanovic B, Lepsanovic Z, Jovcic B, Kojic M. Isolation of Klebsiella pneumoniae producing NDM-1 metallo-beta-lactamase from the urine of an outpatient baby boy receiving antibiotic prophylaxis. Antimicrob 
Agents Chemother. 2012;56(11):6062-3 http://dx.doi.org/10.1128/AAC.00838-12

100. Poirel L, Revathi G, Bernabeu S, Nordmann P. Detection of NDM-1-producing Klebsiella pneumoniae in Kenya. Antimicrob Agents Chemother. 2011;55(2):934-6. http://dx.doi.org/10.1128/AAC.01247-10

101. Gecaj-Gashi A, Hasani A, Bruqi B, Mulliqi-Osmani G. Balkan NDM-1: escape or transplant? Lancet Infect Dis. 2011;11(8):586 http://dx.doi.org/10.1016/S1473-3099(11)70202-X

102. Rimrang B, Chanawong A, Lulitanond A, Wilailuckana C, Charoensri N, Sribenjalux P, et al. Emergence of NDM-1and IMP-14a-producing Enterobacteriaceae in Thailand. Antimicrob Chemother. 2012;67(11):2626-30. http://dx.doi.org/10.1093/jac/dks267

103. Arpin C, Noury P, Boraud D, Coulange L, Manetti A, Andre $C$, et al. Autochthonous case of NDM-1-producing Klebsiella pneumoniae resistant to colistin in a French community patient. Antimicrob Agents Chemother. 2012;56(6):3432-4. http://dx.doi.org/10.1128/AAC.00230-12

104. Denis C, Poirel L, Carricajo A, Grattard F, Fascia P, Verhoeven $P$ et al. Nosocomial transmission of NDM-1producing Escherichia coli within a non-endemic area in France. Clin Microbiol Infect. 2012;18:E128-E130. http://dx.doi.org/10.1111/j.1469-0691.2012.03761.x

105. Nordmann P, Couard JP, Sansot D, Poirel L. Emergence of an autochthonous and community-acquired NDM-1producing Klebsiella pneumoniae in Europe. Clin Infect Dis. 2012;54(1):150-1 http://dx.doi.org/10.1093/cid/cir720

106. Hishinuma A, Ishida T. [New Delhi metallo -betalactamase-1 (NDM-1) producing bacteria]. Nihon Rinsho 2012;70(2):262-6. Japanese.

107. Suzuki S, Yamane K, Wachino J, Matsui M, Konda T, Arakawa Y. [Three months survey of multidrug-resistant Enterobacteriaceae in Japan]. Nihon Rinsho 2012;70(2):18791. Japanese.

108. Yamamoto T, Takano T, Fusegawa T, Shibuya T, Hung WC, Higuchi W, et al. Electron microscopic structures, serum resistance, and plasmid restructuring of $\mathrm{New}$ Delhi metallo-beta-lactamase-1 (NDM-1)-producing ST42 Klebsiella pneumoniae emerging in Japan. J Infect Chemother. 2013;19(1):118-27 http://dx.doi.org/10.1007/s10156-012-0470-z

109. Poirel L, Benouda A, Hays C, Nordmann P. Emergence of NDM-1-producing Klebsiella pneumoniae in Morocco. Antimicrob Chemother. 2011;66(12):2781-3. http://dx.doi.org/10.1093/jac/dkr384

110. Barguigua A, El Otmani F, Lakbakbi El Yaaquobi F, Talmi $M$, Zerouali K, Timinouni M. First report of a Klebsiella pneumoniae strain coproducing NDM-1, VIM-1 and OXA-48 carbapenemases isolated in Morocco. APMIS. 2013;121(7):675-7. http://dx.doi.org/10.1111/apm.12034

111. Kim MN, Yong D, An D, Chung HS, Woo JH, Lee K, et al. Nosocomial clustering of NDM-1-producing Klebsiella pneumoniae sequence type 340 strains in four patients at a South Korean tertiary care hospital. J Clin Microbiol. 2012;50(4):1433-6. http://dx.doi.org/10.1128/JCM.06855-11

112. Poirel L, Schrenzel J, Cherkaoui A, Bernabeu S, Renzi G, Nordmann P. Molecular analysis of NDM-1-producing enterobacterial isolates from Geneva, Switzerland. Antimicrob Chemother. 2011;66(8):1730-3. http://dx.doi.org/10.1093/jac/dkr174

113. McGann P, Hang J, Clifford RJ, Yang Y, Kwak YI, Kuschne RA, et al. Complete sequence of a novel 178-kilobase plasmid carrying bla(NDM-1) in a Providencia stuartii strain isolated in Afghanistan. Antimicrob Agents Chemother. 2012;56(4):1673-9 http://dx.doi.org/10.1128/AAC.05604-11

114. Pasteran F, Albornoz E, Faccone D, Gomes S, Valenzuela C, Morales M, et al. Emergence of NDM-1-producing Klebsiella pneumoniae in Guatemala. I Antimicrob Chemother. 2012;67(7):1795-7. http://dx.doi.org/10.1093/jac/dks101

115. Brink AJ, Coetzee J, Clay CG, Sithole S, Richards GA, Poirel $L$ et al. Emergence of New Delhi metallo-beta-lactamase (NDM-1) and Klebsiella pneumoniae carbapenemase (KPC2) in South Africa. J Clin Microbiol. 2012;50(2):525-7. http://dx.doi.org/10.1128/JCM.05956-11

116. Isozumi R, Yoshimatsu K, Yamashiro T, Hasebe F, Nguyen BM, Ngo TC, et al. bla(NDM-1)-positive Klebsiella pneumoniae from environment, Vietnam. Emerg Infect Dis. 2012;18(8):1383-5.

http://dx.doi.org/10.3201/eid1808.111816
117. Ghazawi A, Sonnevend A, Bonnin RA, Poirel L, Nordmann P, Hashmey R, et al. NDM-2 carbapenemase-producing Acinetobacter baumannii in the United Arab Emirates. Clin Microbiol Infect. 2012;18(2): E34-E36. http://dx.doi.org/10.1111/j.1469-0691.2011.03726.x

118. Shahcheraghi F, Nobari S, Rahmati GF, Nasiri S, Owlia P, Nikbin VS, et al. First report of New Delhi metallo-betalactamase-1-producing Klebsiella pneumoniae in Iran. Microb Drug Resist. 2013;19(1):30-6. http://dx.doi.org/10.1089/mdr.2012.0078

119. Poirel L, Lascols C, Bernabeu S, Nordmann P. NDM-1producing Klebsiella pneumoniae in Mauritius. Antimicrob Agents Chemother. 2012;56(1):598-9. http://dx.doi.org/10.1128/AAC.05639-11

120. Halaby T, Reuland AE, AI NN, Potron A, Savelkoul PH, Vandenbroucke-Grauls CM, et al. A case of New Delhi metallo-beta-lactamase 1 (NDM-1)-producing Klebsiella pneumoniae with putative secondary transmission from the Balkan region in the Netherlands. Antimicrob Agents Chemother. 2012;56(5):2790-1. http://dx.doi.org/10.1128/AAC.00111-12

121. Gil-Romero Y, Sanz-Rodriguez N, Almagro-Molto M, GomezGarces JL. [New description of a NDM-1 carbapenemase producing Klebsiella pneumoniae carrier in Spain]. Enferm Infecc Microbiol Clin 2013;31(6):418-9. Spanish. http://dx.doi.org/10.1016/j.eimc.2012.10.009

122. Chen TL, Fung CP, Lee SD. Spontaneous eradication of a NDM-1 positive Klebsiella pneumoniae that colonized the intestine of an asymptomatic carrier. J Chin Med Assoc. 2011;74(2):104 http://dx.doi.org/10.1016/j.jcma.2011.01.022

123. Stone NR, Woodford N, Livermore DM, Howard J, Pike $\mathrm{R}$, Mushtaq S, et al. Breakthrough bacteraemia due to tigecycline-resistant Escherichia coli with New Delhi metallo-beta-lactamase (NDM)-1 successfully treated with colistin in a patient with calciphylaxis. J Antimicrob Chemother. 2011;66(11):2677-8. http://dx.doi.org/10.1093/jac/dkr337

124. Hornsey M, Phee L, Wareham DW. A novel variant, NDM-5, of the New Delhi metallo-beta-lactamase in a multidrugresistant Escherichia coli ST648 isolate recovered from a patient in the United Kingdom. Antimicrob Agents Chemother. 2011;55(12):5952-4. http://dx.doi.org/10.1128/AAC.05108-11

125. Darley E, Weeks J, Jones L, Daniels V, Wootton M, Macgowan A, et al. NDM-1 polymicrobial infections including Vibrio cholerae. Lancet. 2012;380(9850):1358. http://dx.doi.org/10.1016/S0140-6736(12)60911-8

126. Bilavsky E, Schwaber MJ, Carmeli Y. How to stem the tide of carbapenemase-producing enterobacteriaceae?: proactive versus reactive strategies. Curr Opin Infect Dis. 2010;23(4):327-31. http://dx.doi.org/10.1097/QCO.obo13e32833b3571

127. Centers for Disease Control and Prevention (CDC). Guidance for control of infections with carbapenem resistant or carbapenemase-producing Enterobacteriaceae in acute care facilities. MMWR Morb Mortal Wkly Rep 2009;58(10):256-60.

128. Poirel L, Lagrutta E, Taylor P, Pham J, Nordmann P. Emergence of metallo-beta-lactamase NDM-1-producing multidrug-resistant Escherichia coli in Australia. Antimicrob Agents Chemother. 2010;54(11):4914-6.

129. http://dx.doi.org/10.1128/AAC.00878-10

130. Poirel L, Bonnin RA, Nordmann P. Analysis of the resistome of a multidrug-resistant NDM-1-producing Escherichia coli strain by high-throughput genome sequencing. Antimicrob Agents Chemother. 2011;55(9):4224-9. http://dx.doi.org/10.1128/AAC.00165-11

131. Sidjabat H, Nimmo GR, Walsh TR, Binotto E, Htin A Hayashi Y, et al. Carbapenem resistance in Klebsiella pneumoniae due to the New Delhi Metallo-beta-lactamase. Clin Infect Dis. 2011;52(4):481-4 http://dx.doi.org/10.1093/cid/ciq178

132. Zarfel G, Hoenigl M, Leitner E, Salzer HJ, Feierl G, Masoud $L$ et al. Emergence of New Delhi metallo-beta-lactamase, Austria. Emerg Infect Dis. 2011;17(1):129-30. http://dx.doi.org/10.3201/eid1701.101331

133. Mulvey MR, Grant JM, Plewes K, Roscoe D, Boyd DA. New Delhi metallo-beta-lactamase in Klebsiella pneumoniae and Escherichia coli, Canada. Emerg Infect Dis. 2011;17(1):103-6. http://dx.doi.org/10.3201/eid1701.101358

134. Pillai DR, McGeer A, Low DE. New Delhi metallo-betalactamase-1 in Enterobacteriaceae: emerging resistance. CMAJ. 2011;183(1):59-64 http://dx.doi.org/10.1503/cmaj.101487 
135. Tijet N, Alexander DC, Richardson D, Lastovetska O, Low DE, Patel SN, et al. New Delhi metallo-beta-lactamase, Ontario, Canada. Emerg Infect Dis. 2011;17(2):306-7. http://dx.doi.org/10.3201/eid1702.101561

136. Nielsen JB, Hansen F, Littauer P, Schonning K, Hammerum AM. An NDM-1-producing Escherichia coli obtained in Denmark has a genetic profile similar to an NDM1-producing $E$. coli isolate from the UK. J Antimicrob Chemother. 2012;67(8):2049-51. http://dx.doi.org/10.1093/jac/dks149

137. Diene SM, Bruder N, Raoult D, Rolain JM. Real-time PCR assay allows detection of the New Delhi metallobeta-lactamase (NDM-1)-encoding gene in France. Int Antimicrob Agents. 2011;37(6):544-6. http://dx.doi.org/10.1016/j.ijantimicag.2011.02.006

138. Poirel L, Ros A, Carricajo A, Berthelot P, Pozzetto $B$, Bernabeu $S$ et al. Extremely drug-resistant Citrobacter freundii isolate producing NDM-1 and other carbapenemases identified in a patient returning from India. Antimicrob Agents Chemother. 2011;55(1):447-8 http://dx.doi.org/10.1128/AAC.01305-10

139. Birgy A, Doit C, Mariani-Kurkdjian P, Genel N, Faye A, Arlet $\mathrm{G}$, et al. Early detection of colonization by VIM-1-producing Klebsiella pneumoniae and NDM-1-producing Escherichia coli in two children returning to France. J Clin Microbiol. 2011;49(8):3085-7. http://dx.doi.org/10.1128/JCM.00540-11

140. Pfeifer Y, Witte W, Holfelder M, Busch J, Nordmann P, Poirel L. NDM-1-producing Escherichia coli in Germany. Antimicrob Agents Chemother. 2011;55(3):1318-9. http://dx.doi.org/10.1128/AAC.01585-10

141. McDermott H, Morris D, McArdle E, O'Mahony G, Kelly $\mathrm{S}$, Cormican M, et al. Isolation of NDM-1-producing Klebsiella pnemoniae in Ireland, July 2011. Euro Surveill. 2012;17(7): pii=20087.

142. D’Andrea MM, Venturelli C, Giani T, Arena F, Conte V, Bresciani $P$ et al. Persistent carriage and infection by multidrug-resistant Escherichia coli ST405 producing NDM1 carbapenemase: report on the first Italian cases. J Clin Microbiol. 2011;49(7):2755-8. http://dx.doi.org/10.1128/JCM.00016-11

143. Gaibani P, Ambretti S, Berlingeri A, Cordovana M, Farruggia P, Panico M, et al. Outbreak of NDM-1-producing Enterobacteriaceae in northern Italy, July to August 2011. Euro Surveill. 2011;16(47): pii=20027.

144. Chihara S, Okuzumi K, Yamamoto Y, Oikawa S, Hishinuma A. First case of New Delhi metallo-beta-lactamase 1-producing Escherichia coli infection in Japan. Clin Infect Dis. 2011;52(1):153-4 http://dx.doi.org/10.1093/cid/ciq054

145. Yamamoto T, Takano T, Iwao Y, Hishinuma A. Emergence of NDM-1-positive capsulated Escherichia coli with high resistance to serum killing in Japan. J Infect Chemother. 2011;17(3):435-9. http://dx.doi.org/10.1007/s10156-011-0232-3

146. Jamal W, Rotimi VO, Albert MJ, Khodakhast F, Udo EE, Poirel L. Emergence of nosocomial New Delhi metallo-betaactamase-1 (NDM-1)-producing Klebsiella pneumoniae in patients admitted to a tertiary care hospital in Kuwait. Int Antimicrob Agents. 2012;39(2):183-4. http://dx.doi.org/10.1016/j.ijantimicag.2011.10.002

147. Leverstein-van Hall MA, Stuart JC, Voets GM, Versteeg D, Roelofsen E, Fluit AC. [Carbapenem-resistant Klebsiella pneumoniae following foreign travel]. Ned Tijdschr Geneeskd 2010;154:A2013. Dutch.

148. Williamson DA, Sidjabat HE, Freeman JT, Roberts SA, Silvey A, Woodhouse R, et al. Identification and molecular characterisation of New Delhi metallo-beta-lactamase-1 (NDM-1)- and NDM-6-producing Enterobacteriaceae from New Zealand hospitals. Int J Antimicrob Agents. 2012;39(6):529-33. http://dx.doi.org/10.1016/j.ijantimicag.2012.02.017

149. Samuelsen O, Thilesen CM, Heggelund L, Vada AN, Kummel A, Sundsfjord A. Identification of NDM-1-producing Enterobacteriaceae in Norway. J Antimicrob Chemother. 2011;66(3):670-2. http://dx.doi.org/10.1093/jac/dkq483

150. Poirel L, Al MZ, Al RF, Bernabeu S, Nordmann P. NDM-1producing Klebsiella pneumoniae isolated in the Sultanate of Oman. J Antimicrob Chemother. 2011;66(2):304-6. http://dx.doi.org/10.1093/jac/dkq428

151. Dortet L, Poirel L, Al YF, Nordmann P. NDM-1, OXA-48 and OXA-181 carbapenemase-producing Enterobacteriaceae in Sultanate of Oman. Clin Microbiol Infect. 2012;18(5):E144

http://dx.doi.org/10.1111/j.1469-0691.2012.03796.x
152. Chan HL, Poon LM, Chan SG, Teo JW. The perils of medical tourism: NDM-1-positive Escherichia coli causing febrile neutropenia in a medical tourist. Singapore Med J. 2011;52(4):299-302.

153. Oteo J, Domingo-Garcia D, Fernandez-Romero S, Saez D, Guiu A, Cuevas O, et al. Abdominal abscess due to NDM-1-producing Klebsiella pneumoniae in Spain. J Med Microbiol. 2012;61(Pt 6):864-7. http://dx.doi.org/10.1099/jmm.0.043190-0

154. Sole M, Pitart C, Roca I, Fabrega A, Salvador P, Munoz L, et al. First description of an Escherichia coli strain producing NDM-1 carbapenemase in Spain. Antimicrob Agents Chemother. 2011;55(9):4402-4. http://dx.doi.org/10.1128/AAC.00642-11

155. Poirel L, Bonnin RA, Boulanger A, Schrenzel J, Kaase M, Nordmann P. Tn125-related acquisition of blaNDM-like genes in Acinetobacter baumannii. Antimicrob Agents Chemother. 2012;56(2):1087-9. http://dx.doi.org/10.1128/AAC.05620-11

156. Wu HS, Chen TL, Chen IC, Huang MS, Wang FD, Fung CP, et al. First identification of a patient colonized with Klebsiella pneumoniae carrying blaNDM-1 in Taiwan. J Chin Med Assoc. 2010;73(11):596-8. http://dx.doi.org/10.1016/S1726-4901(10)70129-5

157. Peirano G, Schreckenberger PC, Pitout JD. Characteristics of NDM-1-producing Escherichia coli isolates that belong to the successful and virulent clone ST131. Antimicrob Agents Chemother. 2011;55(6):2986-8. http://dx.doi.org/10.1128/AAC.01763-10

158. Savard P, Gopinath R, Zhu W, Kitchel B, Rasheed JK, Tekle T, et al. First NDM-positive Salmonella sp. strain identified in the United States. Antimicrob Agents Chemother. 2011;55(12):5957-8 http://dx.doi.org/10.1128/AAC.05719-11

159. Centers for Disease Control and Prevention (CDC). Detection of Enterobacteriaceae isolates carrying metallobeta-lactamase - United States, 2010. MMWR Morb Morta Wkly Rep. 2010;59(24):750.

16o. Nakazawa Y, li R, Tamura T, Hoshina T, Tamura K, Kawano $\mathrm{S}$, et al. A case of NDM-1-producing Acinetobacter baumannii transferred from India to Japan. J Infect Chemother. 2013;19(2):330-2. http://dx.doi.org/10.1007/s10156-012-0469-5

161. Cabanes F, Lemant J, Picot S, Simac C, Cousty J, Jalin L, et al. Emergence of Klebsiella pneumoniae and Salmonella metallo-beta-lactamase (NDM-1) producers on reunion island. J Clin Microbiol. 2012;50(11):3812. http://dx.doi.org/10.1128/JCM.01029-12

162. Tsang KY, Luk S, Lo JY, Tsang TY, Lai ST, Ng TK. Hong Kong experiences the 'Ultimate superbug': NDM-1 Enterobacteriaceae. Hong Kong Med J. 2012;18(5):439-41.

163. Peirano G, Pillai DR, Pitondo-Silva A, Richardson D, Pitout JD. The characteristics of NDM-producing Klebsiella pneumoniae from Canada. Diagn Microbiol Infect Dis. 2011;71(12):106-9. http://dx.doi.org/10.1016/j.diagmicrobio.2011.06.013

164. Halaby T, Reuland AE, AI NN, Potron A, Savelkoul PH, Vandenbroucke-Grauls CM et al. A case of New Delh Metallo-beta-Lactamase 1 (NDM-1)-producing Klebsiella pneumoniae with putative secondary transmission from the Balkan Region in the Netherlands. Antimicrob Agents Chemother. 2012;56(5):2790-1. http://dx.doi.org/10.1128/AAC.00111-12

165. Pfeifer Y, Wilharm G, Zander E, Wichelhaus TA, Gottig S, Hunfeld KP, et al. Molecular characterization of blaNDM-1 in an Acinetobacter baumannii strain isolated in Germany in 2007. J Antimicrob Chemother. 2011;66(99):1998-2001. http://dx.doi.org/10.1093/jac/dkr256

166. Bogaerts P, Rezende de CR, Roisin S, Deplano A, Huang TD, Hallin M, et al. Emergence of NDM-1-producing Acinetobacter baumannii in Belgium. J Antimicrob Chemother. 2012;67(6):1552-3. http://dx.doi.org/10.1093/jac/dkso41

167. Mazzariol A, Bosnjak Z, Ballarini P, Budimir A, Bedenic B, Kalenic S, et al. NDM-1-producing Klebsiella pneumoniae, Croatia. Emerg Infect Dis. 2012;18(3):532-4 http://dx.doi.org/10.3201/eid1803.110389 http://dx.doi.org/10.3201/eid1803.1103890

168. Poirel L, Herve V, Hombrouck-Alet C, Nordmann P. Longterm carriage of NDM-1-producing Escherichia coli. Antimicrob Chemother. 2011;66(9):2185-6. http://dx.doi.org/10.1093/jac/dkr236

169. Flateau C, Janvier F, Delacour H, Males S, Ficko C, Andriamanantena $\mathrm{D}$, et al. Recurrent pyelonephritis due to NDM-1 metallo-beta-lactamase producing Pseudomonas 
aeruginosa in a patient returning from Serbia, France, 2012. Euro Surveill. 2012;17(45): $\mathrm{pii}=20311$.

170. Kaase M, Nordmann P, Wichelhaus TA, Gatermann SG, Bonnin RA, Poirel L. NDM-2 carbapenemase in Acinetobacter baumannii from Egypt. J Antimicrob Chemother. 2011;66(6):1260-2. http://dx.doi.org/10.1093/jac/dkr135

171. Nemec A, Krizova L. Carbapenem-resistant Acinetobacter baumannii carrying the NDM-1 gene, Czech Republic, 2011. Euro Surveill. 2012;17(11):pii=20121.

172. Hrabák J, Papagiannitsis CC, Študentová V, Jakubu V, Fridrichová M, Zemlickova H, et al. Carbapenemaseproducing Klebsiella pneumoniae in the Czech Republic in 2011. Euro Surveill. 2013;18(45):pii=20626.

173. Boulanger A, Naas T, Fortineau N, Figueiredo S, Nordmann P. NDM-1-producing Acinetobacter baumannii from Algeria. Antimicrob Agents Chemother. 2012;56(4):2214-5.http:// dx.doi.org/10.1128/AAC.05653-11

174. Lowman W, Sriruttan C, Nana T, Bosman N, Duse A, Venturas J, et al. NDM-1 has arrived: first report of a carbapenem resistance mechanism in South Africa. S Afr Med J. 2011;101(12):873-5.

175. Hammerum AM, Larsen AR, Hansen F, Justesen US, FriisMoller A, Lemming LE, et al. Patients transferred from Libya to Denmark carried OXA-48-producing Klebsiella pneumoniae, NDM-1-producing Acinetobacter baumannii and meticillin-resistant Staphylococcus aureus. Int J Antimicrob Agents. 2012;40(2):191-2. http://dx.doi.org/10.1016/j.ijantimicag.2012.05.003

176. Poirel L, Fortineau N, Nordmann P. International transfer of NDM-1-producing Klebsiella pneumoniae from Iraq to France. Antimicrob Agents Chemother. 2011;55(4):1821-2. http://dx.doi.org/10.1128/AAC.01761-10

177. Poirel L, Ozdamar M, Ocampo-Sosa AA, Turkoglu S, Ozer UG, Nordmann P. NDM-1-producing Klebsiella pneumoniae now in Turkey. Antimicrob Agents Chemother. 2012;56(5):2784-5.http://dx.doi.org/10.1128/AAC.00150-12

178. El-Herte RI, Araj GF, Matar GM, Baroud M, Kanafani ZA, Kanj SS. Detection of carbapenem-resistant Escherichia coli and Klebsiella pneumoniae producing NDM-1 in Lebanon. J Infect Dev Ctries. 2012;6(5):457-61. http://dx.doi.org/10.3855/jidc.2340

179. Baroud M, Dandache I, Araj GF, Wakim R, Kanj S, Kanafani $Z$, et al. Underlying mechanisms of carbapenem resistance in extended-spectrum beta-lactamase-producing Klebsiella pneumoniae and Escherichia coli isolates at a tertiary care centre in Lebanon: role of OXA-48 and NDM-1 carbapenemases. Int J Antimicrob Agents. 2013;41(1):75-9. http://dx.doi.org/10.1016/j.ijantimicag.2012.08.010

180. Lai CC, Lin TL, Tseng SP, Huang YT, Wang JT, Chang SC, et al. Pelvic abscess caused by New Delhi metallo-betalactamase-1-producing Klebsiella oxytoca in Taiwan in a patient who underwent renal transplantation in China. Diagn Microbiol Infect Dis. 2011;71(4):474-5. http://dx.doi.org/10.1016/j.diagmicrobio.2011.09.004

181. Centers for Disease Control and Prevention (CDC). Carbapenem-resistant Enterobacteriaceae containing New Delhi metallo-beta-lactamase in two patients - Rhode Island, March 2012. MMWR Morb Mortal Wkly Rep. 2012;61(24):446-8.

182. Nordmann P, Cuzon G, Naas T. The real threat of Klebsiella pneumoniae carbapenemase-producing bacteria. Lancet Infect Dis. 2009;9(4):228-36. http://dx.doi.org/10.1016/S1473-3099(09)70054-4

183. Leverstein-van Hall MA, Stuart JC, Voets GM, Versteeg D, Tersmette T, Fluit AC. Global spread of New Delhi metallobeta-lactamase 1. Lancet Infect Dis. 2010;10(12):830-1. http://dx.doi.org/10.1016/S1473-3099(10)70277-2

184. Kluytmans-Vandenbergh MF, Kluytmans JA, Voss A. Dutch guideline for preventing nosocomial transmission of highly resistant microorganisms (HRMO). Infection. 2005;33(56):309-13 http://dx.doi.org/10.1007/s15010-005-5079-z

185. Carmeli Y, Akova M, Cornaglia G, Daikos GL, Garau J, Harbarth S, et al. Controlling the spread of carbapenemase-producing Gram-negatives: therapeutic approach and infection control. Clin Microbiol Infect. 2010;16(2):102-11. http://dx.doi.org/10.1111/j.1469-0691.2009.03115.x

186. Johnson S. The ghost map. Riverhead Books. New York: New York; 2006.

187. Khan K, McNabb SJ, Memish ZA, Eckhardt R, Hu W, Kossowsky D, et al. Infectious disease surveillance and modelling across geographic frontiers and scientific specialties. Lancet Infect Dis. 2012;12(3):222-30. http://dx.doi.org/10.1016/S1473-3099(11)70313-9
188. Conroy GC, Anemone RL, Van RJ, Addison A. Google Earth, GIS, and the Great Divide: a new and simple method for sharing paleontological data. J Hum Evol. 2008;55(4):751-5. http://dx.doi.org/10.1016/j.jhevol.2008.03.001

189. Mukherjee J, Llewellyn LE, Evans-Illidge EA. A tropical marine microbial natural products geobibliography as an example of desktop exploration of current research using web visualisation tools. Mar Drugs. 2008;6(4):550-77. http://dx.doi.org/10.3390/md20080028

190. Aanensen DM, Huntley DM, Feil EJ, al-Own F, Spratt BG, EpiCollect: linking smartphones to web applications for epidemiology, ecology and community data collection. PLoS One. 2009;4(9):e6968. http://dx.doi.org/10.1371/journal.pone.0006968

191. Pringle H. Archaeology. Google Earth shows clandestine worlds. Science. 2010;329(5995):1008-9. http://dx.doi.org/10.1126/science.329.5995.1008

192. Jones KE, Patel NG, Levy MA, Storeygard A, Balk D, Gittleman JL, et al. Global trends in emerging infectious diseases. Nature. 2008;451(7181):990-3. http://dx.doi.org/10.1038/nature06536

193. Freifeld CC, MandI KD, Reis BY, Brownstein JS. HealthMap: global infectious disease monitoring through automated classification and visualization of Internet media reports. I Am Med Inform Assoc. 2008;15(2):150-7. http://dx.doi.org/10.1197/jamia.M2544

194. Kwok R. Personal technology: Phoning in data. Nature. 2009;458(7241):959-61. http://dx.doi.org/10.1038/458959a

195. Morris K. Mobile phones connecting efforts to tackle infectious disease. Lancet Infect Dis. 2009;9(5):274. http://dx.doi.org/10.1016/S1473-3099(09)70118-5

196. Dortet L, Poirel L, Anguel N, Nordmann P. New Delhi metallo-beta-lactamase 4-producing Escherichia coli in Cameroon. Emerg Infect Dis. 2012;18(9):1540-2. http://dx.doi.org/10.3201/eid1809.120011

197. Bogaerts P, Bouchahrouf W, de Castro RR, Deplano A, Berhin C, Pierard D et al. Emergence of NDM-1-producing Enterobacteriaceae in Belgium. Antimicrob Agents Chemother. 2011;55(6):3036-8. http://dx.doi.org/10.1128/AAC.00049-11

198. Peirano G, Ahmed-Bentley J, Woodford N, Pitout ID. New Delhi metallo-beta-lactamase from traveler returning to Canada. Emerg Infect Dis. 2011;17(2):242-4. http://dx.doi.org/10.3201/eid1702.101313 